\title{
Membrane-Based Air Composition Control for Light-Duty Diesel Vehicles: A Benefit and Cost Assessment
}

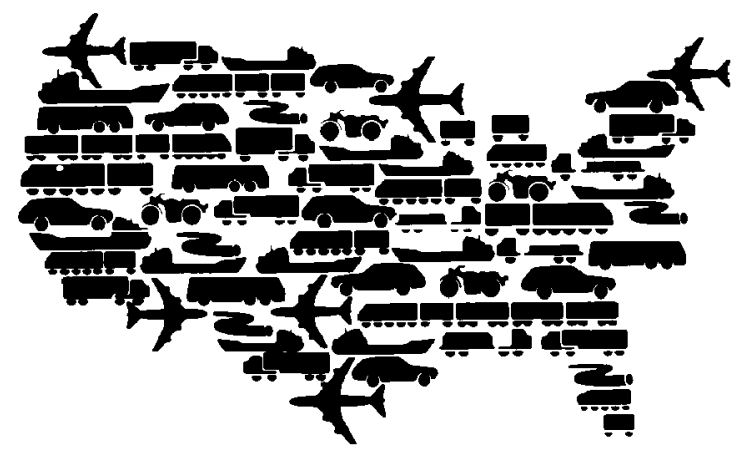

Center for Transportation Research Argonne National Laboratory

Operated by The University of Chicago, under Contract W-31-109-Eng-38, for the United States Department of Energy 


\section{Argonne National Laboratory}

Argonne National Laboratory, with facilities in the states of Illinois and Idaho, is owned by the United States Government, and operated by the University of Chicago under the provisions of a contract with the Department of Energy.

This technical memo is a product of Argonne's Energy Systems (ES) Division. For information on the division's scientific and engineering activities, contact:

Director, Energy Systems Division

Argonne National Laboratory

Argonne, Illinois 60439-4815

Telephone (630) 252-3724

Presented in this technical memo are preliminary results of ongoing work or work that is more limited in scope and depth than that described in formal reports issued by the ES Division.

Publishing support services were provided by Argonne's Information and Publishing Division (for more information, see IPD's home page: http://www.ipd.anl.gov/).

\section{Disclaimer}

This report was prepared as an account of work sponsored by an agency of the United States Government. Neither the United States Government nor any agency thereof, nor any of their employees, makes any warranty, express or implied, or assumes any legal liability or responsibility for the accuracy, completeness, or usefulness of any information, apparatus, product, or process disclosed, or represents that its use would not infringe privately owned rights. Reference herein to any specific commercial product, process, or service by trade name, trademark, manufacturer, or otherwise, does not necessarily constitute or imply its endorsement, recommendation, or favoring by the United States Government or any agency thereof. The views and opinions of authors expressed herein do not necessarily state or reflect those of the United States Government or any agency thereof.

Reproduced directly from the best available copy.

Available to DOE and DOE contractors from the Office of Scientific and Technical Information, P.O. Box 62, Oak Ridge, TN 37831; prices available from (423) 576-8401.

Available to the public from the National Technical Information Service, U.S. Department of Commerce, 5285 Port Royal Road, Springfield, VA 22161. 


\section{Membrane-Based Air Composition Control for Light-Duty Diesel Vehicles: A Benefit and Cost Assessment}

by K. Stork and R. Poola

Center for Transportation Research, Energy Systems Division,

Argonne National Laboratory, 9700 South Cass Avenue, Argonne, Illinois 60439

October 1998

Work sponsored by United States Department of Energy,

Office of Advanced Automotive Technology,

under contract W-31-109-Eng-38 
This report is printed on recycled paper. 
Contents

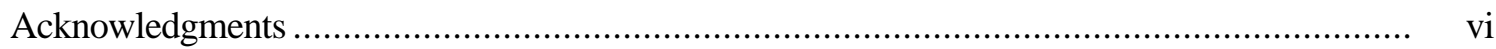

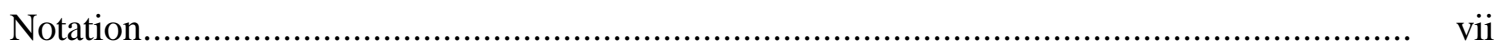

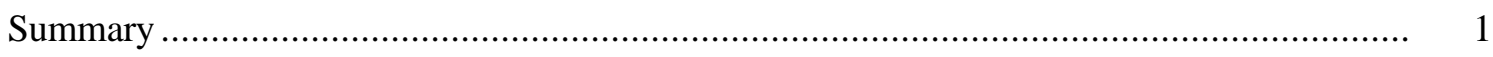

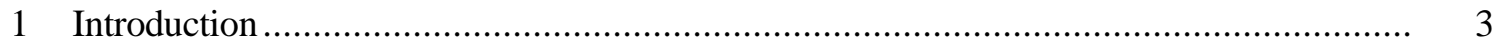

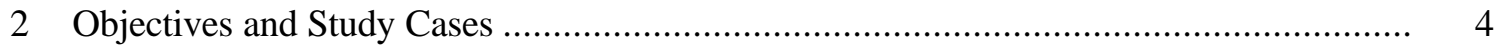

3 Benefits of Air Composition Control for Diesel Engines.................................................. 6

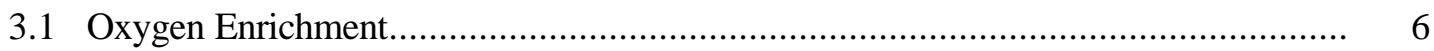

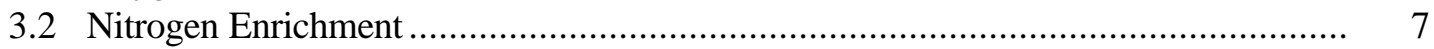

3.3 Variable Air Composition ..................................................................... 10

3.4 Late-Cycle Oxygen Injection .................................................................. 11

4 Membrane Systems: Operation and Design........................................................... 12

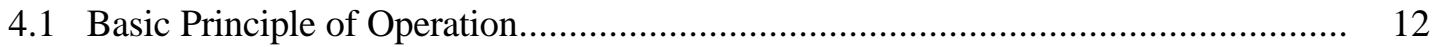

4.2 Membrane Geometry............................................................................ 12

4.2.1 Cartridge Options............................................................................... 13

4.2.2 Operating Modes............................................................................. 14

4.3 Membrane Performance Characteristics...................................................... 15

4.3.1 Intrinsic Properties ................................................................... 15

4.3.2 Polymer Structure ........................................................................ 16

4.3.3 Skin Thickness of Membrane Coating...................................................... 17

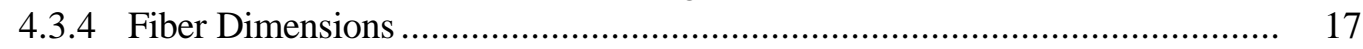

4.3.5 Flow Patterns........................................................................................... 18

4.3.6 Feed Direction....................................................................... 19

4.3.7 Feed Conditions ....................................................................... 19

4.4 Description of Membrane Production Process.................................................... 19

4.5 Membranes for Engine Applications ............................................................ 22

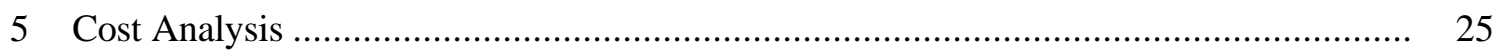

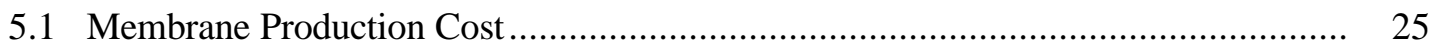

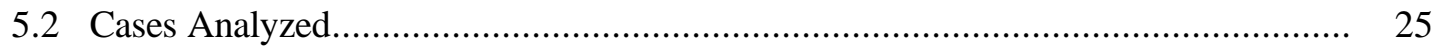

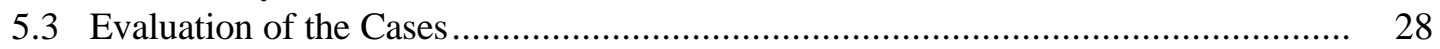

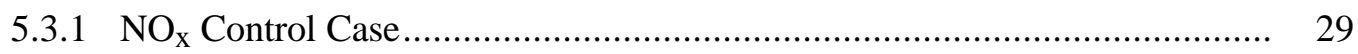

5.3.2 PM Control Case ......................................................................... $\quad 30$

5.3.3 Variable Air Composition Case .............................................................. 31 


\section{Contents (Cont.)}

5.3.4 Power-Enhancement Case ................................................................ 32

5.3.5 Late-Cycle $\mathrm{O}_{2}$ Injection Case .......................................................... 34

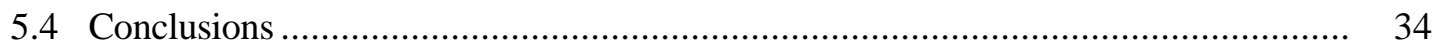

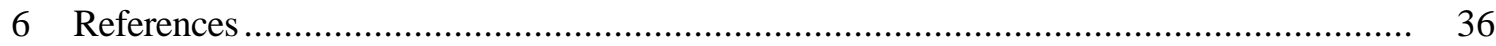

Figures

1 Benefits of $\mathrm{O}_{2}$-Enriched Combustion for Diesel Engines ....................................... 8

2 Argonnes Pulsed Plasma Arc System Generates Monatomic $\mathrm{N}_{2}$ for $\mathrm{NO}_{\mathrm{x}}$ Reduction ........ 10

3 Conceptual Scheme of Variable Air Composition Supply System

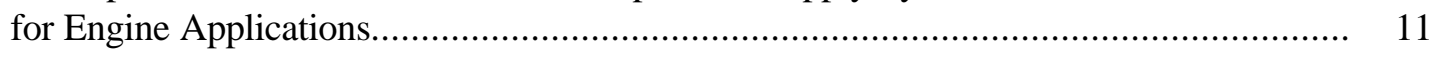

4 Basic Principle of Solution-Diffusion Membranes...................................................... 12

5 Geometries of Flat-Film and Hollow-Fiber Membranes............................................ 13

6 Schematic of a Counterflow Hollow-Fiber Membrane Module with Shell-and-Tube Geometry ...................................................................... 14

7 Air Separation Membrane Modes of Operation..................................................... 14

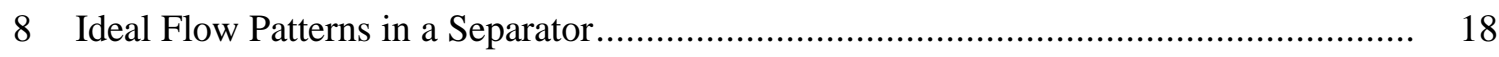

9 Process Flowchart for Membrane Production .................................................... 21

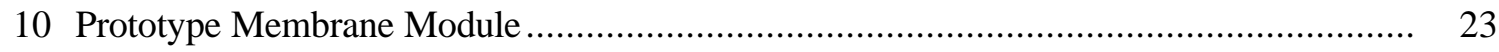

11 Current and Projected Membrane Cost as a Function of Surface Area Manufactured ............................................................................. 28

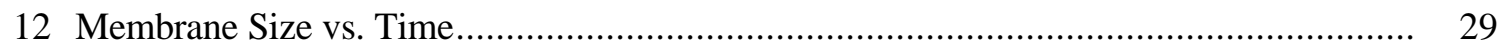

$13 \mathrm{~N}_{2}$-Enrichment Module Cost Curves ................................................................... 30

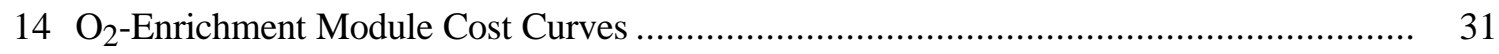

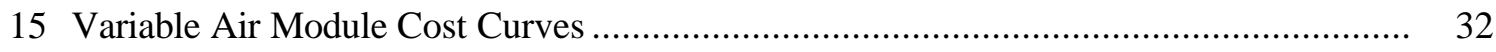




\section{Figures (Cont.)}

16 Power-Enhancement $\mathrm{O}_{2}$ Module Cost Curves ......................................................... 33

17 Late-Cycle $\mathrm{O}_{2}$ Injection Module Cost Curves .......................................................... 35

\section{Tables}

1 Membrane Cases and Competing Technologies ................................................. 5

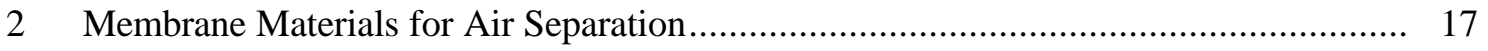

3 Comparison of CMS Polymers with Silicon Rubber .............................................. 22

4 Performance of Prototype Modules Developed at CMS ............................................. 24

$5 \quad$ Process-Based Cost of Membrane Manufacture .......................................................... 26

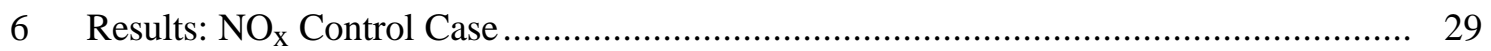

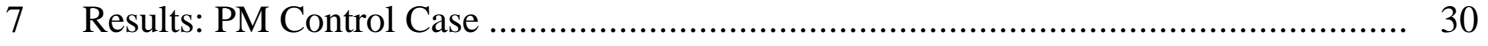

8 Results: Variable Air Composition Case ................................................................. 32

$9 \quad$ Results: Power-Enhancement Case ...................................................................... 33

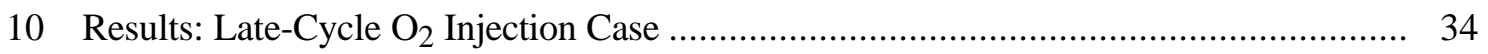

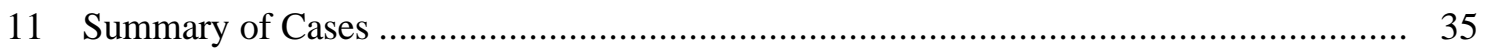




\section{Acknowledgments}

The work reported here was supported by the U.S. Department of Energy, Office of Advanced Automotive Technology (OAAT), under contract W-31-109-Eng-38. The authors would like to thank Ken Howden and Patrick Davis of the OAAT for commissioning this study. The authors would also like to thank Stuart Nemser and David Rodeffer, both of Compact Membrane Systems, Inc., for technical advice and modeling assistance. 


\section{Acronyms}

\begin{tabular}{|c|c|}
\hline CI & compression ignition \\
\hline CIDI & compression-ignition, direct-injection \\
\hline CMS & Compact Membrane Systems, Inc. \\
\hline $\mathrm{CO}$ & carbon monoxide \\
\hline CRADA & Cooperative Research and Development Agreement \\
\hline DI & direct injection \\
\hline DMAC & $\mathrm{N}, \mathrm{N}$-dimethyl acetamide \\
\hline DOE & U.S. Department of Energy \\
\hline EGR & exhaust-gas recirculation \\
\hline FTP & Federal Test Procedure \\
\hline $\mathrm{HC}$ & hydrocarbon \\
\hline $\mathrm{Hg}$ & mercury \\
\hline ID & inside diameter \\
\hline IDI & indirect injection \\
\hline LNC & lean- $\mathrm{NO}_{\mathrm{x}}$ catalyst \\
\hline MY & model year \\
\hline $\mathrm{N}_{2}$ & nitrogen \\
\hline $\mathrm{NO}, \mathrm{NO}_{2}$ & constituents of $\mathrm{NO}_{\mathrm{x}}$ \\
\hline $\mathrm{NO}_{\mathrm{X}}$ & nitrogen oxides \\
\hline $\mathrm{O}_{2}$ & oxygen \\
\hline OAAT & Office of Advanced Automotive Technology \\
\hline OD & outside diameter \\
\hline $\mathrm{OH}$ & hydroxide ion \\
\hline PDD & perfluoro-2-2-dimethyl-1-3 dioxole \\
\hline PM & particulate matter \\
\hline PNGV & Partnership for a New Generation of Vehicles \\
\hline SAE & Society for Automotive Engineers \\
\hline SCR & selective catalytic reduction \\
\hline SI & spark ignition \\
\hline $\mathrm{SO}_{2}$ & sulfur dioxide \\
\hline SRI & Stanford Research Institute \\
\hline STP & standard temperature and pressure \\
\hline TDC & top dead center \\
\hline TDI & turbocharged direct injection \\
\hline TFE & tetrafluoroethylene \\
\hline
\end{tabular}




\section{Units of Measure}

$\begin{array}{ll}\mu_{\AA} & \text { micrometer } \\ \AA & \text { angstrom } \\ \text { barrer } & \mathrm{cm}^{3}(\mathrm{STP})-\mathrm{cm} / \mathrm{cm}^{2}-\mathrm{s}-\mathrm{cm} \mathrm{Hg} \times 10^{10} \\ \mathrm{cfm} & \text { cubic foot per minute } \\ \mathrm{cm}^{2} & \text { square centimeter } \\ \mathrm{cm}^{3} & \text { cubic centimeter } \\ \mathrm{g} / \mathrm{mi} & \text { gram per mile } \\ \mathrm{gal} & \text { gallon } \\ \mathrm{GPU} & \text { gas permeation unit }(\mathrm{s})=\mathrm{cm}^{3}(\mathrm{STP}) / \mathrm{cm}^{2}-\mathrm{s}-\mathrm{cm} \mathrm{Hg} \times 10^{10} \\ \mathrm{~h} & \text { hour } \\ \mathrm{hp} & \text { horsepower } \\ \text { in. } & \text { inch } \\ \mathrm{kW} / \mathrm{L} & \text { kilowatt per liter } \\ \mathrm{L} & \text { liter } \\ \mathrm{m}{ }^{2} & \text { square meter } \\ \mathrm{mpg} & \text { mile per gallon } \\ { }^{\circ} \mathrm{C} & \text { degree Celsius } \\ \mathrm{PM} & \text { particulate matter measuring } 10 \text { micrometers or less } \\ \mathrm{PM} & \text { particulate matter measuring } 2.5 \text { micrometers or less } \\ \mathrm{psi} & \text { pound per square inch } \\ \mathrm{psig} & \text { pound per square inch gauge } \\ \mathrm{rpm} & \text { rotation per minute } \\ \mathrm{s} & \text { second } \\ \mathrm{scfm} & \text { standard cubic foot per minute } \\ \mathrm{wt} \% & \text { percentage by weight } \\ & \end{array}$




\section{Summary}

This report presents the methodologies and results of a study conducted by Argonne National Laboratory (Argonne) to assess the benefits and costs of several membrane-based technologies. The technologies evaluated will be used in automotive emissions-control and performance-enhancement systems incorporated into light-duty diesel vehicle engines. Such engines are among the technologies that are being considered to power vehicles developed under the government-industry Partnership for a New Generation of Vehicles (PNGV).

Emissions of nitrogen oxides $\left(\mathrm{NO}_{\mathrm{x}}\right)$ from diesel engines have long been considered a barrier to use of diesels in urban areas. Recently, particulate matter (PM) emissions have also become an area of increased concern because of new regulations regarding emissions of particulate matter measuring 2.5 micrometers or less $\left(\mathrm{PM}_{2.5}\right)$. Particulates are of special concern for diesel engines in the PNGV program; the program has a research goal of 0.01 gram per mile $(\mathrm{g} / \mathrm{mi})$ of particulate matter emissions under the Federal Test Procedure (FTP) cycle. This extremely low level (one-fourth the level of the Tier II standard) could threaten the viability of using diesel engines as stand-alone powerplants or in hybrid-electric vehicles. The techniques analyzed in this study can reduce $\mathrm{NO}_{\mathrm{x}}$ and particulate emissions and even increase the power density of the diesel engines used in light-duty diesel vehicles.

For nearly a decade, Argonne has been evaluating membrane-based methods to control the composition of air used in combustion. Membranes are the only practical method of modifying air composition for on-board use. The applicability of the technique depends strongly on both the technical and economic feasibility of implementing it on a vehicle. Over the past 10 years, significant technical advances have been made in the development of air-separation membranes. Researchers have developed and commercialized novel membrane materials that can efficiently separate air at the concentrations required for vehicle applications and have developed compact membrane modules that can be incorporated into vehicle design.

Previous analysis by Argonne and others has demonstrated the effectiveness of oxygen enrichment at reducing PM, smoke, hydrocarbon (HC), and carbon monoxide (CO) emissions while increasing engine power output. Under appropriate oxygen-enriched operating conditions, diesel engines have achieved a net increase of $1020 \%$ in power density and a decrease of $3060 \%$ in PM emissions. Nitrogen-enriched air can be used as an alternative to exhaust gas recirculation to control $\mathrm{NO}_{\mathrm{x}}$ emissions and can also be used to generate a monatomic nitrogen plasma for exhaust post-treatment to reduce emissions of $\mathrm{NO}_{\mathrm{x}}$.

Argonne has recently identified an operating regime that can simultaneously reduce $\mathrm{NO}_{\mathrm{x}}$ and PM while increasing power output when oxygen-enriched combustion air is used. This promising technique, which will be verified by additional experimental work at Argonne (using a range of engine sizes), will require the use of membranes similar to those analyzed in this study. 
In this study, five membrane-based performance and emission control systems (hereafter, "cases") are analyzed. The systems are optimized to achieve the following objectives: $\mathrm{NO}_{\mathrm{x}}$ control, PM control, power-density enhancement, and optimized $\mathrm{NO}_{\mathrm{x}}$ and $\mathrm{PM}$ control over a driving cycle. A final case is added to characterize a membrane system suitable for use with a new concept developed at Argonne to control PM emissions by injecting oxygen-enriched air directly into a cylinder during the expansion stroke.

The cost of the system developed for each case was estimated by means of a production process-based model developed for this study. The largest single cost, and the only area with significant potential for technical improvement and further cost reductions, is the membrane material itself. Other aspects of the systems - from auxiliary pumps to membrane casings and supports - are already produced in commercial quantities and cannot be expected to benefit from economies of scale. Improvements in membrane material coating processes using new materials, however, can be reasonably expected to reduce the cost of mass-produced systems. So a range of costs for mass-produced systems has been developed, with current membrane costs and reductions of up to one-third being assumed. These costs are presented in the following table.

\begin{tabular}{|clc|}
\hline $\begin{array}{c}\text { Case } \\
\text { Number }\end{array}$ & \multicolumn{1}{c|}{ Case Description } & Projected Mass-Production Cost \\
\hline & $\mathrm{NO}_{\mathrm{x}}$ Control with Nitrogen Enrichment & $\$ 75-110$ \\
2 & $\mathrm{PM}$ Control with Oxygen Enrichment & $\$ 140-200$ \\
3 & Variable Air Composition for Minimum & $\$ 190-265$ \\
& Driving-Cycle Emissions & $\$ 180-260$ \\
4 & Power Enhancement with Oxygen Enrichment & $\$ 100-120$ \\
5 & Late-Cycle Oxygen-Enriched Air Injection & \\
\hline
\end{tabular}

Each case was compared with an alternative technology expected to provide similar benefits. The alternatives and their expected costs are listed in the following table.

\begin{tabular}{|c|c|c|}
\hline Case Number & Alternative Technology & Approximate Cost of Alternative \\
\hline 1 & Lean $\mathrm{NO}_{x}$ Catalyst $+\mathrm{EGR}$ & $\$ 300$ \\
\hline 2 & PM Trap + Fuel Additives & $\$ 200+\$ 0.02 / \mathrm{gal}$ \\
\hline 3 & LNC, EGR + PM Trap & $\$ 500$ \\
\hline 4 & $\begin{array}{l}\text { Larger Engine or } \\
\text { Turbocharging }\end{array}$ & $\begin{array}{l}\text { ??? } \\
\text { (probably }>10 \% \text { engine cost) }\end{array}$ \\
\hline 5 & PM Trap + Fuel Additives & $\$ 200+\$ 0.02 / \mathrm{gal}$ \\
\hline
\end{tabular}

The results of our process-based systems cost analysis reveal that the costs of membranebased performance and emission-control methods are competitive with those of expected alternative techniques. 


\section{Section 1 Introduction}

Argonne National Laboratory's (Argonne's) Center for Transportation Research has been investigating oxygen- and nitrogen-enrichment technologies for emissions control and performance enhancement in internal combustion engines - particularly in diesel engines - for nearly a decade. To exploit the benefits of air-composition modification, a technology must be able to provide both oxygen $\left(\mathrm{O}_{2}\right)$ - and nitrogen $\left(\mathrm{N}_{2}\right)$-enriched air in controlled amounts, at specified enrichment levels, and with good transient response. Furthermore, a self-contained, compact, and cost-effective system must be used to supply the required $\mathrm{O}_{2}$-enriched or $\mathrm{N}_{2}$ enriched air.

Membrane-based air separation is the only practical method available to effect the necessary separation. Alternative systems, while appropriate for some stationary applications (e.g., pressure-swing adsorption), are too energy-intensive and bulky for automotive systems. Over the past 10 years, significant advances in membrane science and technology have reduced the size and energy requirements of appropriate membrane systems to make them technically feasible for automotive applications.

Section 2 of this report presents the objectives of the study and the five cases developed to compare the costs and benefits of various membrane technologies. The cases for representative applications of membranes to diesel engines are based on a modern light-duty diesel engine. We designed the membrane systems to meet the demands of each case, and we compare each case to an alternative technology in terms of function and cost. Section 3 summarizes the benefits of aircomposition control, and Section 4 describes the structure, operating principles, design, and application of various membrane technologies. Because the cost analysis was to be processbased, the membrane production process is also described. From this production process, a simple cost model is derived, and the costs of the resultant membrane systems are compared with those of competing technologies (Section 5). 


\section{Section 2 Objectives and Study Cases}

The Compression-Ignition, Direct-Injection (CIDI) Engine Program Office of the U.S. Department of Energy's (DOE's) Office of Advanced Automotive Technology (OAAT) requested that Argonne perform a process-based cost analysis of a membrane system suitable for vehicle application. The purpose of the study was to quantify the current and potential future costs of various membrane systems, including auxiliary equipment, membrane manufacture, and system integration in a vehicle. This report documents the methods and results of our study.

Because this study was undertaken for the CIDI Program Office, its focus was on light-duty diesel engines - specifically, a 1.9-liter (L) Volkswagen turbocharged direct-injection (TDI) diesel engine with a peak power of 90 horsepower (hp). Such an engine, probably incorporated into a hybrid-electric vehicle, is a leading contender to power a high-mileage vehicle being developed as part of the Partnership for a New Generation of Vehicles (PNGV) program. Although the PNGV program vehicles might use a smaller engine, this production engine is modern and available, and specifications and some data on the engine have been published. The PNGV program goal is to produce a passenger vehicle with triple the fuel economy of a 1990 model year (MY) four-door sedan (to achieve approximately 80 miles per gallon [mpg]) with no sacrifice of safety, comfort, pollution control, or cost relative to the 1990 vehicle. Achieving this goal will require enormous advances in automotive engineering - a combination of technologies will almost certainly be required.

In order to present the cost of membrane systems in an appropriate context, we evaluated the benefits of air-composition control and compared the costs of the cases we developed with those of alternative systems expected to provide similar emissions or performance benefits. These competing technologies, and the membrane cases to which they correspond, are listed in Table 1.

For each case, costs were estimated at three volume levels of production corresponding to a total number of membrane modules that would require similar active membrane surface areas. Because of the different flow-rate and composition requirements of each case, the number of modules produced under constant scale assumptions for each case varied.

The main source for cost estimates for the competing technologies was a report entitled Diesel Emission Control Options (Environex, Inc., 1997), which contains a broad survey of current and developing control technologies. 
Table 1 Membrane Cases and Competing Technologies

\begin{tabular}{|c|c|c|c|}
\hline $\begin{array}{l}\text { Case } \\
\text { Number }\end{array}$ & Case Description & Membrane Type & Competing Technology \\
\hline 1 & $\begin{array}{l}\mathrm{N}_{2} \text {-Enrichment } \\
\text { for } \mathrm{NO}_{x} \text { Control }\end{array}$ & $\begin{array}{l}\mathrm{N}_{2} \text { Membrane } \\
100 \mathrm{cfm} \text { at } 81 \% \mathrm{~N}_{2}\end{array}$ & $\begin{array}{l}\text { Lean } \mathrm{NO}_{x} \text { Catalyst } \\
\text { (+ Hydrocarbon Reductant) }\end{array}$ \\
\hline 2 & $\begin{array}{l}\mathrm{O}_{2} \text {-Enrichment } \\
\text { for PM Control }\end{array}$ & $\begin{array}{l}\mathrm{O}_{2} \text { Membrane } \\
100 \mathrm{cfm} \text { at } 23 \% \mathrm{O}_{2}\end{array}$ & $\begin{array}{l}\text { Particulate Trap and } \\
\text { Fuel Additives }\end{array}$ \\
\hline 3 & $\begin{array}{l}\text { Variable Air Composition for } \\
\mathrm{NO}_{\mathrm{x}} \text { and PM Control }\end{array}$ & $\begin{array}{l}\mathrm{O}_{2} / \mathrm{N}_{2} \text { Membrane } \\
100 \mathrm{cfm} \text { at } 23 \% \mathrm{O}_{2} \text { or } 81 \% \mathrm{~N}_{2}\end{array}$ & LNC + Particulate Trap \\
\hline 4 & $\begin{array}{l}\mathrm{O}_{2} \text { for Increased } \\
\text { Power Density }\end{array}$ & $\begin{array}{l}\mathrm{O}_{2} \text { Membrane } \\
100 \mathrm{cfm} \text { at } 25 \% \mathrm{O}_{2}\end{array}$ & Larger Engine or Turbocharging \\
\hline 5 & $\begin{array}{l}\text { Late-Cycle } \mathrm{O}_{2} \text { Injection for In- } \\
\text { Cylinder PM Control }\end{array}$ & $\begin{array}{l}\mathrm{O}_{2} \text { Membrane } \\
10 \mathrm{cfm} \text { at } 30 \% \mathrm{O}_{2}\end{array}$ & $\begin{array}{l}\text { Particulate Trap and } \\
\text { Fuel Additives }\end{array}$ \\
\hline
\end{tabular}

Notes:

$\mathrm{NO}_{\mathrm{x}}=$ nitrogen oxides, $\mathrm{N}_{2}=$ nitrogen, cfm = cubic foot per minute, $\mathrm{PM}=$ particulate matter, $\mathrm{O}_{2}=$ oxygen, and $\mathrm{LNC}=$ lean $-\mathrm{NO}_{\mathrm{x}}$ catalyst. 


\section{Section 3 \\ Benefits of Air Composition Control for Diesel Engines}

Because of its high compression ratio and lean operation, the diesel engine has excellent thermal efficiency. Traditionally, however, diesel engines have not been considered clean engines, because of the emissions that result from their operation. In the United States, diesel penetration in the light-duty segment of the automotive market is negligible.

Its potential for high fuel economy has made the diesel engine one of several options considered to power the PNGV program vehicle. However, use of the diesel presents several significant challenges; the power density of diesel vehicles is insufficient to meet the 80-mpg goal of the program in a stand-alone configuration and - perhaps an even greater challenge current diesel engines cannot meet the emissions goals of the program. It is uncertain whether even medium- and heavy-duty diesel engines, sold commercially in the United States, can meet PNGV emissions standards in the relatively near future. For the light-duty engines, engineers will encounter similar problems.

Much attention has been given to reducing $\mathrm{NO}_{\mathrm{x}}$ emissions in diesels. Because of the wellknown $\mathrm{NO}_{\mathrm{x}} / \mathrm{PM}$ trade-off, efforts to reduce $\mathrm{NO}_{\mathrm{x}}$ have tended to increase particulate emissions. This is a problem even in heavy vehicles - one that will increase as PM standards are tightened. It is of particular concern to the PNGV program because the PM emission research goal (0.01 grams per mile [g/mi] $\mathrm{PM}_{10}$ ) is $75 \%$ lower than the Tier II standard for light-duty vehicles not included in the PNGV program. So, the use of diesel engines in PNGV program vehicles poses a major challenge in reducing both $\mathrm{NO}_{\mathrm{x}}$ and $\mathrm{PM}$ emissions. The authors believe that the membrane systems described in this study will go a long way toward solving the emissions and performance problems presented by using diesel engines in PNGV program vehicles.

Many in-cylinder and exhaust post-treatment techniques have been and are currently being investigated to reduce $\mathrm{NO}_{\mathrm{x}}$ and $\mathrm{PM}$ emissions to acceptable levels. Altering the composition of air via membrane separation provides automotive engineers with a new design tool to solve difficult environmental problems. Membrane systems are now (or soon will be) available to provide $\mathrm{O}_{2}$-enriched and $\mathrm{N}_{2}$-enriched air from a single on-board module. This study addresses such critical issues as the cost, size, and power of such systems.

\subsection{Oxygen Enrichment}

Studies of the effects of $\mathrm{O}_{2}$-enrichment on both direct-injection (DI) and indirect-injection (IDI) diesel engines have been carried out with the objective of reducing smoke, particulates, hydrocarbons (HC), and carbon monoxide (CO) emissions (Karim and Ward 1968; Ghojel et al. 1983; Watson et al. 1990; Virk et al. 1993). Most of these studies reveal significant reductions in exhaust emissions, with the exception of $\mathrm{NO}_{\mathrm{x}}$ emissions. 
With increased $\mathrm{O}_{2}$ content in the combustion air, additional fuel is burned, thereby increasing the power output. Oxygen enrichment of combustion air allows ignition with minimum amounts of premixed fuel, because it reduces the ignition delay period (Iida et al. 1986). As a result, both the rate of pressure rise and the peak cylinder pressure are low. Oxygen-enriched combustion air also promotes combustion with alternative fuels, as well as lowgrade and water-emulsified fuels (Sekar et al. 1990). With higher $\mathrm{O}_{2}$ levels in the combustion air, the flame temperatures are higher, which increases in-cylinder formation of $\mathrm{NO}_{\mathrm{x}}$ emissions. The reduction in the ignition delay period helps retard the injection timing (without adversely affecting power and particulate emissions) so that $\mathrm{NO}_{\mathrm{x}}$ emissions can be reduced to a certain extent, but it is difficult to attain the baseline $\mathrm{NO}_{\mathrm{x}}$ levels.

Figure 1a shows that the increase of particulate emissions caused by retarded injection timing is smaller when $\mathrm{O}_{2}$-enriched intake air is used than when ambient intake air is used. Figure $1 \mathrm{~b}$ shows an increase in cylinder power output with a disproportionately small increase in peak cylinder pressure. Both of these figures represent data from a 2.5-L, single-cylinder Caterpillar diesel truck engine (Sekar et al. 1990).

Despite the many benefits of $\mathrm{O}_{2}$ enrichment, the accompanying increase in $\mathrm{NO}_{\mathrm{x}}$ emissions hinders its widespread application. This problem can be addressed in a number of ways, including using a post-treatment device. Recent studies conducted at Argonne have identified an $\mathrm{O}_{2}$-enriched operating regime (defined by the combination of various operating parameters) that can eliminate the increase in $\mathrm{NO}_{\mathrm{x}}$ emissions, reduce $\mathrm{PM}$ emissions, and increase power output. If the results of the initial experiments can be confirmed for a variety of engines, this new approach may be used to attain the benefits of $\mathrm{O}_{2}$-enrichment without increasing $\mathrm{NO}_{\mathrm{x}}$ or reducing fuel economy or engine performance. At this time, the data from these studies cannot be published because they were collected under a Cooperative Research and Development Agreement (CRADA).

\subsection{Nitrogen Enrichment}

Nitrogen-enriched air from polymer membranes has been used for a number of years in such applications as food storage and inert blanketing of chemically sensitive products. Its application to combustion engines is technically new.

For In-Cylinder Combustion - A number of $\mathrm{NO}_{\mathrm{x}}$ control methods are aimed at lowering in-cylinder combustion temperatures by increasing the specific heat capacity of the charge and/or by lowering the $\mathrm{O}_{2}$ concentration. One such technique is exhaust-gas recirculation (EGR), in which part of the exhaust gas is mixed with the ambient intake air. This method, the most costeffective way of reducing $\mathrm{NO}_{\mathrm{x}}$ emissions from spark-ignition (SI) engines, is being considered by many investigators for use with compression-ignition (CI) engines (Dürnholz et al. 1992; Ladommatos et al. 1996; Psaras et al. 1997). However, its applicability for diesel engines is uncertain because of such drawbacks as increases in both particulates and smoke at higher engine loads, reduced engine durability (Nagai et al. 1983), and possible oil contamination caused by sulfur dioxide $\left(\mathrm{SO}_{2}\right)$ and soot particles in recirculated exhaust gas (Nagaki and Korematsu 1995). 

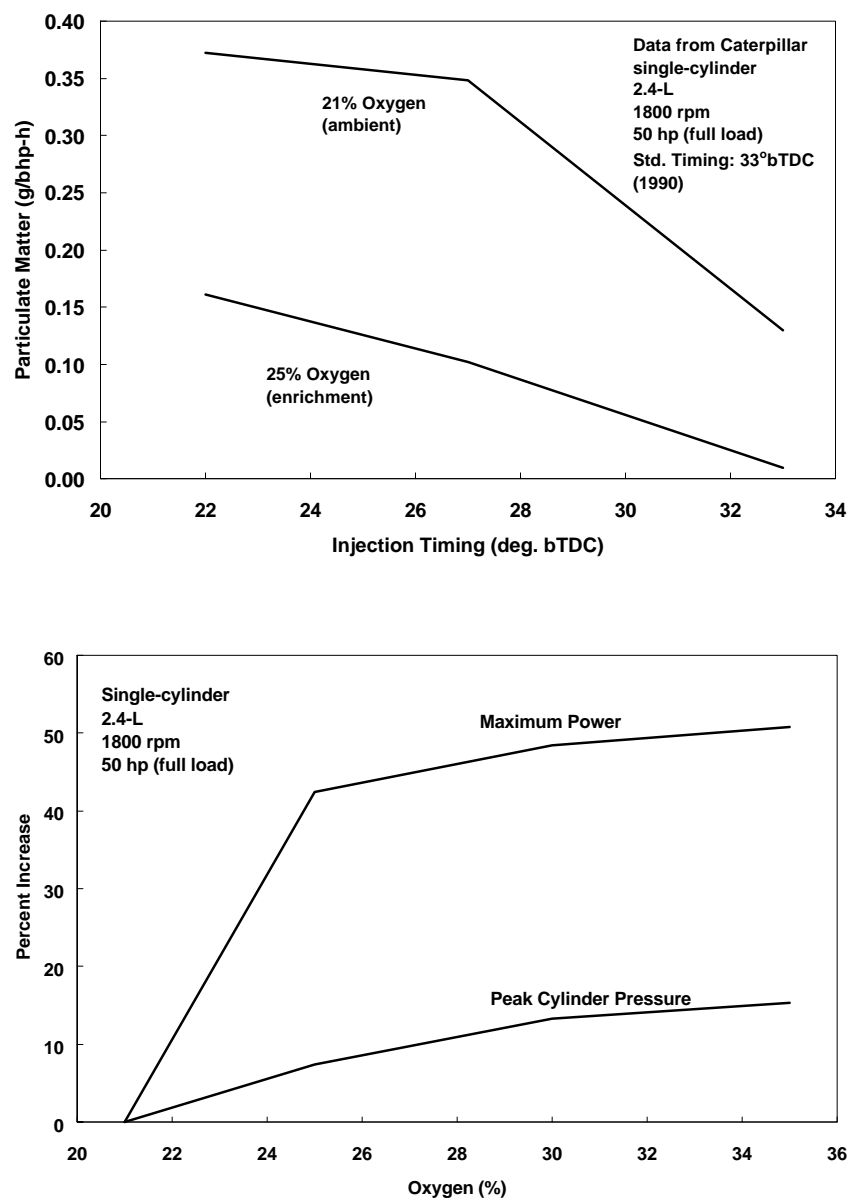

Figure 1 Benefits of $\mathrm{O}_{2}$-Enriched Combustion for Diesel Engines (a: change in PM as function of injection timing; $b$ : change in power with cylinder pressure)

In diesel engines, the $\mathrm{NO}_{\mathrm{x}}$ reductions that can be achieved by using EGR vary with the amount of recirculated gases to be mixed with the ambient air, exhaust gas temperature and water content, fuel injection timing, and operating conditions. Arcoumanis et al. (1995) report that warm, uncooled, recirculated exhaust gases increase the temperature of the intake mixture, which speeds combustion and increases the formation of $\mathrm{NO}$ (the primary component of $\mathrm{NO}_{\mathrm{x}}$ ). Despite the simplicity of EGR, a heat exchanger would be necessary to cool the exhaust gases to further reduce $\mathrm{NO}_{\mathrm{x}}$ emissions. However, cooled, dry, recirculated gases eliminate the water vapor, making the heat capacity lower than with the hot exhaust. Increasing the EGR rate would lead to lower $\mathrm{NO}_{\mathrm{x}}$ emissions but increased soot, $\mathrm{CO}$, and $\mathrm{HC}$ emissions. Also, because of unwanted species in the recirculated exhaust gases, it is difficult to obtain an optimal $\mathrm{NO}_{\mathrm{x}} / \mathrm{PM}$ trade-off without sacrificing performance and fuel economy. 
$\mathrm{Yu}$ and Shahed (1981) maintain that local atomic $\mathrm{O}_{2}$ concentration and local temperature during combustion are the primary variables that affect the formation of NO. Studies at Volkswagen AG (Röpke et al. 1995) and Imperial College (Arcoumanis et al. 1995) indicate that increasing the EGR rate by up to $30 \%$ would lower the intake $\mathrm{O}_{2}$ concentration by about $4 \%$ (by volume) at an excess air factor of 1.5 .

A similar decrease in the concentration of $\mathrm{O}_{2}$ in the intake air can easily be achieved by using $\mathrm{N}_{2}$-enriched air supplied by an air separation membrane. Used as a diluent, $\mathrm{N}_{2}$-enriched air can be an effective way to lower the $\mathrm{O}_{2}$ concentration, thereby lowering $\mathrm{NO}_{\mathrm{x}}$ formation during combustion. The reductions in $\mathrm{NO}_{\mathrm{x}}$ emissions achieved by adding $\mathrm{N}_{2}$-enriched air would be similar to those obtained with EGR but without its deleterious effects. The advantages of using $\mathrm{N}_{2}$-enriched intake air rather than EGR include elimination of the following problems: (1) unwanted exhaust species in the intake; (2) the need for a heat exchanger to cool the gases; (3) poor utilization of fresh air; and (4) oil contamination, piston ring failures, and wear. So, use of $\mathrm{N}_{2}$-enriched intake air can be considered an effective alternative to EGR in reducing $\mathrm{NO}_{\mathrm{x}}$ emissions from diesel engines.

Many investigators (Plee et al. 1981; Bowen et al. 1996; Li et al. 1997) have reported reductions in $\mathrm{NO}_{\mathrm{x}}$ emissions from diesel engines by using $\mathrm{N}_{2}$-enriched air. However, all these engine tests were conducted using bottled $\mathrm{N}_{2}$, primarily to simulate EGR effects. The authors, for the first time, have conducted engine tests using an air separation membrane; the results were reported at the 1998 Society for Automotive Engineers (SAE) Congress (Callaghan et al. 1998).

For Exhaust Post-Treatment - When excited nitrogen $\left(\mathrm{N}^{*}\right)$ atoms generated by an arc are supplied to exhaust gas containing $\mathrm{NO}$, the extended Zeldovich reaction of $\mathrm{N}$ atoms with $\mathrm{NO}, \mathrm{O}_{2}$, and $\mathrm{OH}$ (hydroxide ion) takes place. Hilliard and Weinberg (1976) showed that NO decreases with time, on the basis of reactions of $\mathrm{N}$ with $\mathrm{NO}$ and $\mathrm{O}_{2}$ :

$$
\mathrm{N}^{*}+\mathrm{NO} \rightarrow \mathrm{N}_{2}+\mathrm{O}
$$

Morimune and Ejiri (1994) examined the influences of $\mathrm{O}_{2}, \mathrm{SO}_{2}$, carbon dioxide $\left(\mathrm{CO}_{2}\right)$, and water $\left(\mathrm{H}_{2} \mathrm{O}\right)$ contained in the engine exhaust gas on the reduction of $\mathrm{NO}_{\mathrm{x}}$. They observed $\mathrm{NO}_{\mathrm{x}}$ removal rates of $40-50 \%$ with an $\mathrm{O}_{2}$ concentration of $3-5 \%$ and plasma power of 600 watts (W). $\mathrm{Ng}$ et al. (1995) reported on the effectiveness of monatomic nitrogen, induced by a pulsed plasma arc, in reducing $\mathrm{NO}$ and $\mathrm{NO}_{2}$ (nitrogen dioxide, another constituent of $\mathrm{NO}_{\mathrm{x}}$ ) in the gas mixture $\left(\mathrm{N}_{2}+\mathrm{NO}+\mathrm{NO}_{2}+\mathrm{O}_{2}\right)$. Figure 2 shows Argonne's pulsed plasma arc system.

The availability of pure nitrogen to generate monatomic nitrogen is critical for successful implementation of this technique in vehicular systems. Argonne is pursuing a method that uses $\mathrm{N}_{2}$-enriched air generated by an air separation membrane, thereby eliminating the need for $\mathrm{N}_{2}$ cylinders in the vehicle. The currently available polymer membranes can generate a purity of about $95 \% \mathrm{~N}_{2}$ quite economically; achieving $99 \%+$ purity is less cost-effective. 


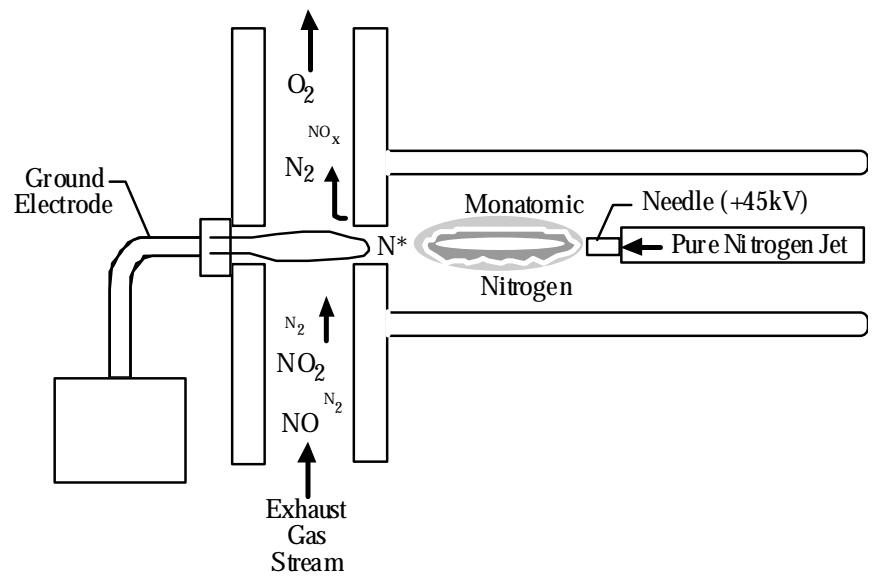

Figure 2 Argonne's Pulsed Plasma Arc System Generates Monatomic $\mathrm{N}_{2}$ for $\mathrm{NO}_{\mathrm{x}}$ Reduction

In addition to $\mathrm{O}_{2}$ and $\mathrm{N}_{2}$ enrichment, Argonne evaluated the following applications: variable-air composition and late-cycle $\mathrm{O}_{2}$ injection. Both are conceptual, based on work performed by Argonne researchers over the past few years. Neither technique has been tested and no data are available to demonstrate their effectiveness, but they are promising extensions of the concept of modification of intake air.

\subsection{Variable Air Composition}

The usefulness of $\mathrm{N}_{2}$ - and $\mathrm{O}_{2}$-enriched combustion can be combined by using both product streams of a membrane module selectively during engine operation to reduce $\mathrm{NO}_{\mathrm{x}}$ under highload conditions (with $\mathrm{N}_{2}$ enrichment) and PM under all other conditions (with $\mathrm{O}_{2}$ enrichment). The $\mathrm{N}_{2}$-enriched stream could also be diverted for use in a nonthermal plasma after-treatment device, as described in Section 3.2.

Figure 3 shows the conceptual scheme of variable air composition with a membrane operating in vacuum mode. A bypass valve is provided downstream of the air filter to allow controlled ambient air to flow through the membrane. The $\mathrm{O}_{2}$-enriched (permeate) or $\mathrm{N}_{2}$-enriched (retentate) air is collected in a small plenum (optional) to regulate the air supply into the engine intake. By selective use of either permeate or retentate streams from the membrane, the composition of engine intake air can be varied. An electronic control unit can select the desired $\mathrm{O}_{2} / \mathrm{N}_{2}$ ratio in the intake air and the duration of its operation to obtain the lowest exhaust emissions, on the basis of engine load and speed. If reformed air is not required, bypass valves can be manipulated to allow the air to pass directly from air filter to engine intake. Nitrogen-enriched air from the membrane can also be used for exhaust post-treatment devices (such as the pulsed plasma arc system developed by Argonne to generate monatomic nitrogen) to reduce $\mathrm{NO}_{\mathrm{x}}$ emissions to very low levels. 


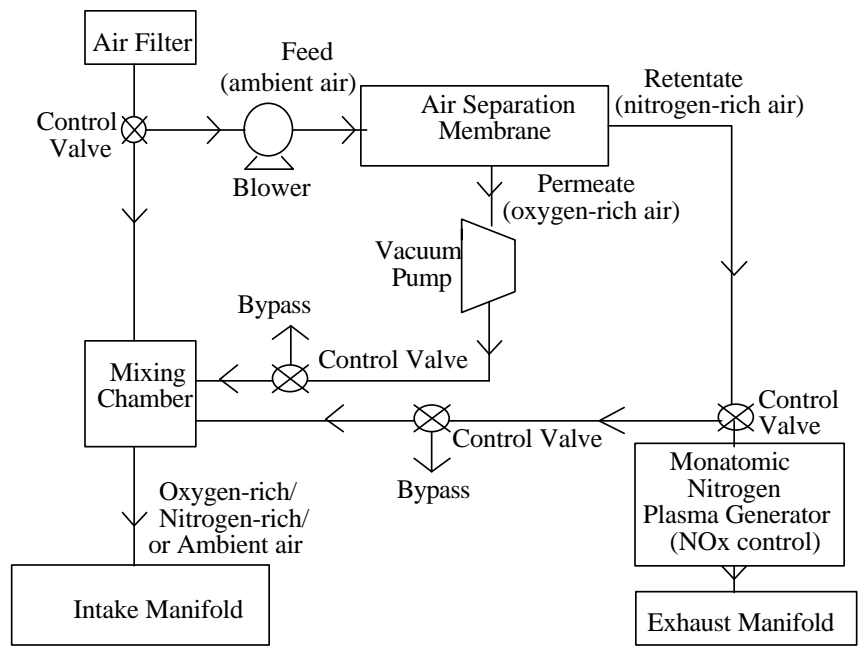

Figure 3 Conceptual Scheme of Variable Air Composition Supply System for Engine Applications

\subsection{Late-Cycle Oxygen Injection}

Soot and $\mathrm{NO}_{\mathrm{x}}$ form during combustion under different conditions. By analyzing combustion, Argonne has developed a method to control PM without increasing $\mathrm{NO}_{\mathrm{x}}$. We call this method "late-cycle injection of $\mathrm{O}_{2}$-enriched air" and have applied for a patent for the technique.

During the later part of the expansion process, temperatures in the combustion chamber are generally below those that favor the formation of $\mathrm{NO}_{\mathrm{x}}$. Under these conditions, a small amount of $\mathrm{O}_{2}$-enriched air is injected directly into the cylinder to enhance combustion of soot. If the concept works, both $\mathrm{NO}_{\mathrm{x}}$ and $\mathrm{PM}$ should be reduced relative to base levels.

In order to implement this concept, engineers would need to design an $\mathrm{O}_{2}$-enriched air injector as part of a cylinder and incorporate a small but powerful compressor to compress a small amount of air (approximately $10 \mathrm{cfm}$ in the case of the Volkswagen TDI engine) to a high pressure (500-2,000 pounds per square inch [psi]). This new concept will require significant additional research if it is found to be promising. 


\section{Section 4 \\ Membrane Systems: Operation and Design}

The preceding discussions demonstrate that air separation membranes represent a key element in controlling vehicle combustion and emissions. It is important, then, to understand the mechanism of air separation and the conditions that influence its effectiveness so that membranes can be developed and optimized for specific applications. This section describes the basic operating principles of membranes and membrane geometry, performance characteristics, the production process, and membranes used for engine applications.

\subsection{Basic Principle of Operation}

Air delivered to engines can be enriched in $\mathrm{O}_{2}$ or $\mathrm{N}_{2}$ by selective permeation through nonporous, polymeric membranes via a well-known "solution-diffusion" mechanism (Winston Ho 1992). Air molecules dissolve into the membrane and then diffuse across it, as illustrated in Figure 4.

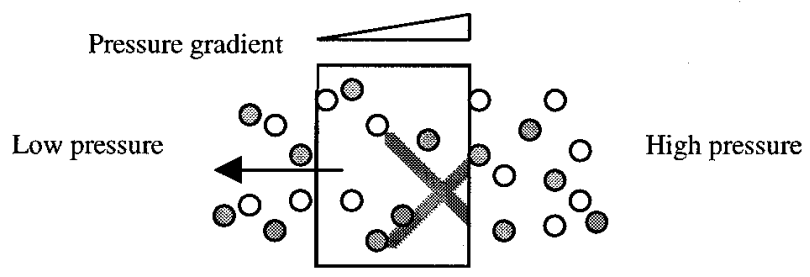

Figure 4 Basic Principle of Solution-Diffusion Membranes

The air, fed to the membrane device at elevated pressure, passes along one side of the membrane. The opposite side of the membrane is held at a lower pressure. The pressure differential and concentration gradient across the membrane provide the driving force for the dissolution and diffusion of $\mathrm{O}_{2}$ and $\mathrm{N}_{2}$ molecules across the membrane. Because the intrinsic rate of dissolution-diffusion of oxygen is greater than that of $\mathrm{N}_{2}$, oxygen diffuses more rapidly and becomes enriched in the low-pressure stream, called the permeate stream. The $\mathrm{N}_{2}$-enriched portion of the air that is swept out without crossing the membrane, the retentate, is necessary to effect separation.

\subsection{Membrane Geometry}

In general, membrane material is coated onto a porous support that provides mechanical strength and the ability to tolerate the pressure differentials imposed during operation (Henis and Tripodi 1980) The membrane geometry influences the manner in which the membrane is 
packaged. Two geometries are commonly used: flat films and hollow fibers. Figure 5 shows flat-film and hollow-fiber membranes. Hollow fibers offer excellent packaging compared to flat films because hollow fibers are self-supporting. The inside and outside diameters of the fibers range from $100-500 \mu \mathrm{m}$ and 500-1,000 $\mu \mathrm{m}$, respectively. The membrane material, the ratio of the fiber's outside diameter (OD) and inside diameter (ID), and the detailed structure of the membrane determine the maximum external and internal pressures at which the membranes can operate.

Membranes are assembled into a cartridge in the final package (referred to as a membrane module or membrane separator) for operation.

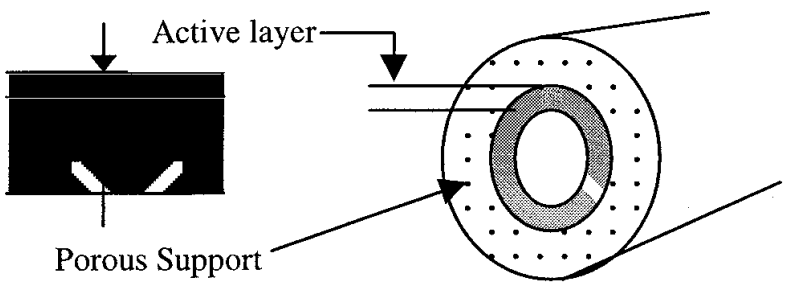

Flat Film

Hollow Fiber

Figure 5 Geometries of Flat-Film and Hollow-Fiber Membranes

\subsubsection{Cartridge Options}

Whether the membrane is fabricated as a flat sheet or a hollow fiber, it must be incorporated into a "package" that is readily usable. A compact membrane cartridge design should have a high packaging density, because permeate flow per unit membrane area is inherently low. Flatsheet, spiral-wound, and hollow-fiber geometries are the three membrane cartridge options available; each has its advantages and limitations.

Flat-sheet modules resemble plate-and-frame press filters. They are relatively easy to fabricate but provide the lowest surface area per unit volume. Spiral-wound cartridges consist of a number of leaves, each containing two flat sheets of membrane separated by porous support material. Spiral-wound cartridges are reasonably compact, and system designs incorporating spirals require a simple pressure vessel. However, air bypass around the cartridges caused by misalignment or failure within the pressure vessel may reduce the effectiveness of spiral-wound cartridges. Hollow-fiber cartridges consist of small hollow-fiber bundles sealed with an adhesive into header plates at opposite ends of the module - this design allows a large number of fibers in the cartridge. The packing density of the hollow-fiber cartridge is the highest by far, and the unit is simple to operate and maintain on clean air streams (Koros and Chern 1987) Typically, a hollow-fiber membrane module resembles a shell-and-tube geometry. Figure 6 illustrates the arrangement of a typical hollow-fiber membrane module (Baker et al. 1990). 


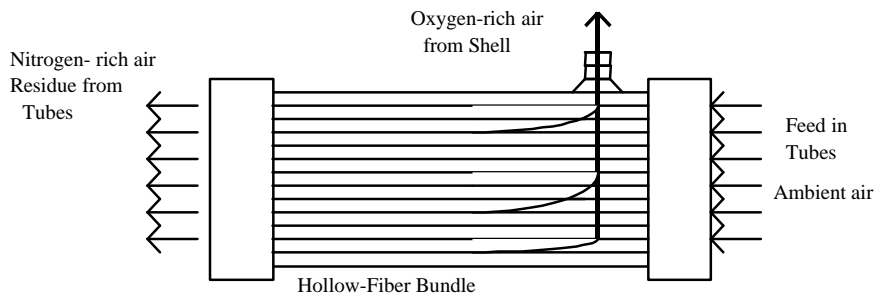

Figure 6 Schematic of a Counterflow Hollow-Fiber Membrane Module with Shell-and-Tube Geometry

\subsubsection{Operating Modes}

Air separation membrane units can be operated in either vacuum or pressure mode, as illustrated in Figure 7. In the vacuum mode, the feed air is pressurized to only slightly above atmospheric pressure (1-3 pounds per square inch gauge [psig]), and a vacuum (5-20 inches of mercury [in. $\mathrm{Hg}]$ ) is maintained on the permeate side of the membrane. The retentate is vented at atmospheric pressure. The vacuum mode is typically more energy-efficient than the pressure mode, primarily because a vacuum is applied only to the permeate (product stream).

In the pressure mode, the feed air is typically pressurized to several (1-5) atmospheres, while permeate is maintained at about atmospheric pressure. Higher driving forces are obtained in this mode because the differential pressures are higher than those of the vacuum mode, resulting in reduced membrane area requirements.

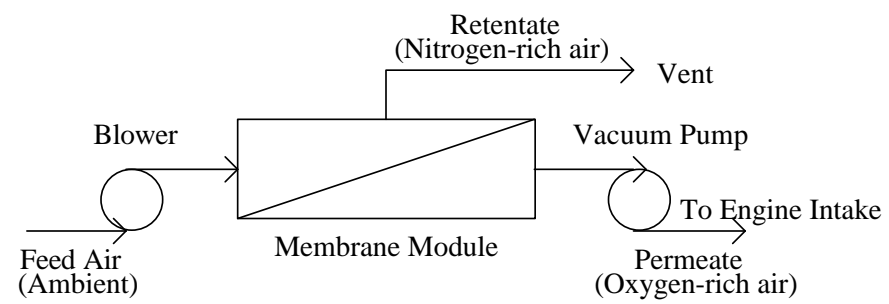

Membrane Operating on Vacuum Mode for Oxygen-Enriched Air

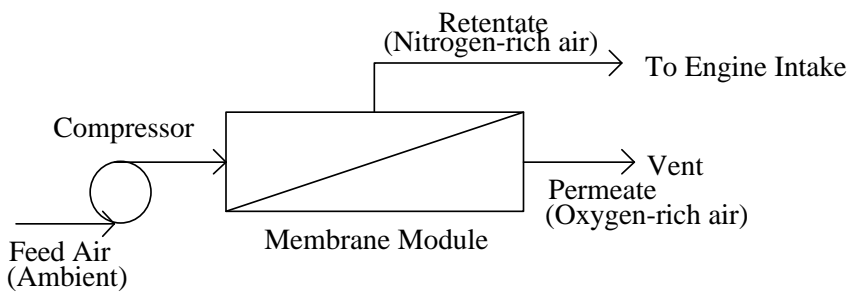

Membrane Operating on Pressure Mode for Nitrogen-Enriched Air

Figure 7 Air Separation Membrane Modes of Operation 
For $\mathrm{O}_{2}$-enriched air applications, the vacuum mode is more energy-efficient and so more suitable. However, because of the limited differential pressure, the vacuum mode requires a larger membrane area than the pressure mode.

For $\mathrm{N}_{2}$-enriched air applications, the pressure mode is more suitable because the retentate can be obtained at conditions closer to feed conditions, allowing only flow loss in the tubes. The pressure mode is more energy-intensive when used for $\mathrm{O}_{2}$-enriched air applications, because both permeate and retentate have to be compressed to higher pressures.

In certain applications, vacuum and pressure modes can be used in order to obtain the benefits of both. In such a "mixed mode" of operation, the feed air is pressurized, and a partial vacuum is maintained on the permeate side to increase both the pressure (feed-to-permeate) ratio and differential pressure (feed-to-retentate), and thus, the $\mathrm{O}_{2}$ concentration. The oxygen-enriched permeate is then mixed with an ambient air stream to obtain the desired air flow and oxygen concentration.

The selection of a mode of operation depends on the economic trade-offs among membrane area costs, auxiliary equipment costs, input power requirements to maintain the required pressure or vacuum, and the compactness of the system.

\subsection{Membrane Performance Characteristics}

The performance of an air separator depends on the membrane's intrinsic properties and on several other parameters, such as geometry (cartridge type, packaging density, and arrangement of separators), membrane polymer structure, skin thickness, geometry of the fibers, fiber dimensions, flow pattern, feed direction, and feed conditions. The selection of a membrane to achieve the desired $\mathrm{O}_{2}$-enriched or $\mathrm{N}_{2}$-enriched airflow is based on the power required to maintain the differential pressure across the membrane and the amount of space the separator occupies. The following sections briefly summarize the influence of certain key parameters on the performance of air separation membranes. More details can be found in Winston Ho (1992), Koros and Chern (1987), and Baker et al. (1990).

\subsubsection{Intrinsic Properties}

Membrane material is characterized by its permeability and selectivity, which are intrinsic for a given structure. The permeability, $\mathrm{P}_{\mathrm{r}}$, of a given gas is closely associated with Henry's law for simple, noninteracting gases and for low concentrations. The permeability is calculated by using the following equation (Winston Ho 1992; Gollan and Kleper 1985; Ragland and Whipple 1989):

$$
\mathrm{P}_{\mathrm{ri}}=\mathrm{S}_{\mathrm{i}} \times \mathrm{D}_{\mathrm{i}}
$$

where $P_{r i}$ is permeability of gas " $\mathrm{i}$ " in the membrane ( $\mathrm{cm}^{3}$ (STP) $\mathrm{cm} / \mathrm{cm}^{2}-\mathrm{s}-\mathrm{cm}-\mathrm{Hg}$ ); $\mathrm{S}_{\mathrm{i}}$ is the solubility of gas " $i$ " in the membrane $\left(\mathrm{cm}^{3}(\mathrm{STP}) / \mathrm{cm}^{3} \mathrm{~cm}-\mathrm{Hg}\right)$; and $\mathrm{D}_{\mathrm{i}}$ is the diffusivity of gas 
"i” in the membrane $\left(\mathrm{cm}^{2} / \mathrm{s}\right)$. (STP signifies "standard temperature and pressure.") Fick's law can be used to describe the overall permeability, a function of flow as well as of membrane composition, as follows:

$$
\mathrm{N}_{\mathrm{i}}=\frac{\mathrm{P}_{\mathrm{ri}} \mathrm{A} \Delta \mathrm{P}}{\delta}
$$

where $\mathrm{N}_{\mathrm{i}}$ is the flow rate of gas "i" $\left(\mathrm{cm}^{3}(\mathrm{STP}) / \mathrm{s}\right)$; $\mathrm{A}$ is membrane area $\left(\mathrm{cm}^{2}\right)$; $\delta$ is the membrane coating thickness $(\mathrm{cm})$; and $\Delta \mathrm{P}$ is the trans-membrane partial-pressure difference of gas " $\mathrm{i}$ " $(\mathrm{cm}$ of $\mathrm{Hg}$ ).

Equation 3 indicates that the degree of separation between $\mathrm{O}_{2}$ and $\mathrm{N}_{2}$ depends on their relative permeabilities in the membrane material. This ratio of permeabilities is known as selectivity, or the separation factor. The separation factor $(\alpha)$ between $\mathrm{O}_{2}$ and $\mathrm{N}_{2}$ can be calculated as follows:

$$
\alpha=\frac{\mathrm{P}_{\mathrm{rO} 2}}{\mathrm{P}_{\mathrm{rN} 2}}
$$

The larger the value of the separation factor, the more complete the separation. The stage cut $(\varphi$, or recovery) of an air separator is another important measure of performance; it is simply the permeate flow rate divided by the feed flow rate.

\subsubsection{Polymer Structure}

The effectiveness of polymeric solution-diffusion membranes for air separation depends on the chemistry of the polymers and its influence on the rate at which air molecules diffuse through the membrane. Rubbery and glassy polymers are the two classes of conventional materials used for air separation. A rubbery polymer is an amorphous polymeric material that is used at temperatures above its softening or glass transition temperature. These materials generally possess high permeability and low selectivity. A glassy polymer is an amorphous polymeric material that is used at temperatures below its softening or glass transition temperature. Because of the more restricted segmental motions in glassy polymers, these materials offer better selectivity than do rubbery polymers (at the cost of lower permeability).

As a result of growing interest in air separation membranes, a host of new materials (grouped as polycarbonates and polymides) have been developed; these materials are specifically designed to enhance air permeability and selectivity. Table 2 lists the different membrane materials for $\mathrm{O}_{2} / \mathrm{N}_{2}$ separation. Membrane manufacturers are also vigorously pursuing development of newer materials that have superior properties for air separation. For example, perfluoro-2-2-dimethyl-1-3-dioxole (PDD) copolymerized with tetrafluoroethylene (TFE), under development at Compact Membrane Systems, Inc. (CMS), represents a new family of glassy membrane materials with high $\mathrm{O}_{2}$ permeability and good selectivity for $\mathrm{O}_{2} / \mathrm{N}_{2}$ separation (Nemser and Roman 1991). 
Table 2 Membrane Materials for Air Separation

\begin{tabular}{|lcc|}
\hline \multicolumn{1}{|c|}{ Polymer } & $\begin{array}{c}\text { Permeability } \\
\text { (barrera) }\end{array}$ & Selectivity \\
\hline $\begin{array}{l}\text { Rubbery polymers } \\
\text { (e.g., silicon rubber, natural rubber, } \\
\text { polychloroprene) }\end{array}$ & $600-900$ & $2.0-2.5$ \\
$\begin{array}{l}\text { Glassy polymers } \\
\text { (e.g., ethyl cellulose, cellulose } \\
\text { acetate) }\end{array}$ & $1-20$ & $4.0-8.0$ \\
$\begin{array}{l}\text { Polycarbonates } \\
\text { Poly(imides) }\end{array}$ & $1.0-4.0$ & $3.0-7.0$ \\
\hline
\end{tabular}

Sources: Winston Ho 1992; Koros and Chern 1987; Brandup and Immergut 1975; Stern 1994.

${ }^{\text {a }}$ barrer $=\mathrm{cm}^{3}(\mathrm{STP})-\mathrm{cm} / \mathrm{cm}^{2}-\mathrm{S}-\mathrm{cm} \mathrm{Hg} \times 10^{10}$.

Dow Chemical Company has patented a series of halogenated polycarbonates and polyestercarbonates that have high $\mathrm{O}_{2} / \mathrm{N}_{2}$ selectivities (Anand et al. 1989).

\subsubsection{Skin Thickness of Membrane Coating}

For compact modules, the skin thickness of a membrane coating on a porous support (hollow fibers) is critical. The rate of air transport across the membrane is inversely proportional to the skin thickness of the membrane (active) layer. For commercial membranes, skin thickness is typically on the order of 1,000-2,000 angstroms $(\AA)$; a thickness of 200-800 $\AA$ is attainable in more finely tuned membranes (Nemser 1997). Membrane material is applied to a porous support by spraying, immersion, or circulation of membrane material in a solvent (one that is not a solvent for the support material). Apart from the skin thickness, the morphology of the membrane across the entire thickness also influences the ultimate performance of the membrane.

\subsubsection{Fiber Dimensions}

Flow loss in the fiber bore can be significant if the bore diameter is small and the permeate flow rate is high. In hollow-fiber membrane systems, the fiber size is an important factor for packaging. Fiber sizes ranging from 50 to $2,000 \mu \mathrm{m}$ are currently available. Larger fiber sizes offer less tube flow restriction, but their packaging density is lower than that of smaller-diameter fibers. There is a trade-off between the packaging density and pressure drop across the fibers. The internal and outside diameters of the fibers should be selected on the basis of the expected permeate flow rate per fiber, fabrication technology, and mechanical strength required. 
In order to achieve higher flow rates through the membrane, membrane surface area $(\mathrm{A}=$ $\pi \mathrm{dln}$ ) needs to be increased. This area can be increased either by increasing the length $(\ell)$ or diameter (d) of the fiber or by increasing the number of fibers (n). However, the increase in pressure drop associated with longer length is higher than the increase that would be observed with a larger diameter, as the Hagen-Poiseuille flow equation demonstrates:

$$
\Delta \mathrm{P}=\frac{128 \mu \ell \mathrm{N}}{\mathrm{d}^{2}}
$$

where " $\mu$ " is fluid viscosity and " $\mathrm{N}$ " is the flow rate. Therefore, the preferred practice to increase module flow output is to increase the fiber diameter and thus, the module diameter.

\subsubsection{Flow Patterns}

The performance of a membrane separator is affected by the relative directions of feed and permeate flow in the vicinity of the active layer of the membrane and/or the relative flow directions of the feed and permeate streams. The ideal flow patterns in a membrane are shown in Figure 8 (Winston Ho 1992). The feed and permeate streams may be directed cocurrently or countercurrently to one another. Crossflow permeation, with the permeate stream perpendicular to the membrane, is also possible. For co- and countercurrent permeation, the air in contact with the downstream side of the membrane consists of air that has just permeated through the membrane and permeate that is flowing past it. For cross-flow permeation, on the other hand, permeate that is in contact with the active layer consists entirely of air that has just passed through the membrane. Pan and Habgood (1974) reported that the countercurrent flow pattern is the best and that the cross-flow pattern is intermediate with respect to membrane area, enrichment, or stage cut. (Also, multiple permeate outlets make possible such hybrid flow patterns as the countercurrent-cocurrent flow depicted in Figure 8.)

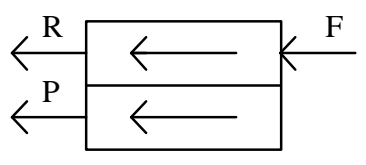

Cocurrent plug flow

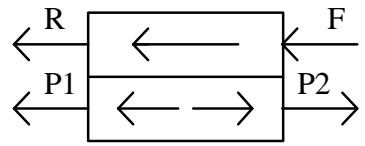

Countercurrent-cocurrent plug flow

F: Feed P: Permeate

R: Residue

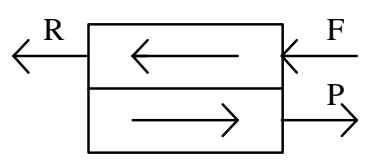

Countercurrent plug flow

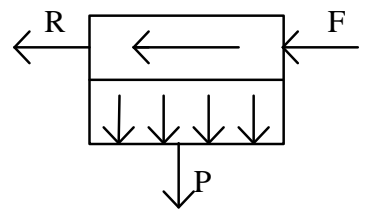

Cross flow

Figure 8 Ideal Flow Patterns in a Separator 


\subsubsection{Feed Direction}

In shell-side feed separators, the feed (air) is brought into contact with the outer surface of the membrane fibers. Air permeates into the fiber and then flows down the fiber bore. From there, it passes through the tubesheet and out of the module. In tube-side feed separators (for example, see Figure 7), the feed is directed to the bore of the fibers. Two tubesheets are required - feed air is introduced through one, while nonpermeating air exits from the other. The choice between shell-side and tube-side feed in hollow-fiber modules is generally made on the basis of whether an $\mathrm{O}_{2}$ - or $\mathrm{N}_{2}$-enriched stream is the desired product.

\subsubsection{Feed Conditions}

Ragland and Whipple (1989) reported that raising the feed pressure results in a higherpurity permeate product when the separator is operated at the same fractional stage cut (recovery), although the extent of the increase diminishes at higher feed pressures. Undoubtedly, an increase in the feed pressure will lower the membrane area needed to obtain a given permeate recovery.

Temperature is also an important variable that directly affects the physical properties of the membrane, and hence its permeability and selectivity. The temperature limits for membranes are related to the glass transition temperature of the polymer. The permeability (product of the solubility and mobility coefficients) tends to be dominated by the diffusivity and increases with increasing temperature. On the other hand, the separation factor is moderated in its temperature dependence, because the temperature dependencies of the permeabilities of the $\mathrm{N}_{2}$ and $\mathrm{O}_{2}$ are rather similar.

The higher percentages of relative humidity in feed air do not appreciably affect the permeation, because water vapor readily permeates the membrane. In comparing the permeability coefficients of $\mathrm{H}_{2} \mathrm{O}, \mathrm{N}_{2}$, and $\mathrm{O}_{2}$ for several polymers, the permeability of $\mathrm{H}_{2} \mathrm{O}$ is at least two orders of magnitude greater than those of either $\mathrm{O}_{2}$ or $\mathrm{N}_{2}$ (Brandup and Immergut 1975). However, membrane materials are susceptible to oil contamination. It is particularly important for engine applications to avoid placing wet-type air filters and/or oil-cooled pumping elements (blower/compressor/vacuum pump) upstream of the membrane.

The selection of a membrane to achieve the desired $\mathrm{N}_{2}$ - and $\mathrm{O}_{2}$-enriched airflow is based on the power required to maintain a pressure differential across the membrane and the amount of space it occupies. The inherent trade-offs among membrane properties and design parameters suggest that a detailed evaluation should be conducted to select or design a membrane system suitable for a given application.

\subsection{Description of Membrane Production Process}

The membrane manufacturing process described here was adapted from a 1991 report by Stanford Research Institute (SRI) (Schwaar 1991) and a private 1992 DuPont study (Lopez 1991). 
While other membrane production processes are available and have been described, the two studies used in this analysis had the advantages that both included cost analyses and the SRI study included material requirements for production of hollow-fiber membrane modules.

Conceptually, the process was broken down into five distinct subprocesses: hollow-fiber spinning, hollow-fiber drying, fiber-bundle potting, module assembly, and membrane coating. The first four are commercial processes employed for making membranes with uncoated fibers (for liquid-gas mixture, for example). The deposition of an ultra-thin layer of nonporous membrane material on the (porous) hollow-fiber substrate, along with the development of effective membrane materials, is the key to manufacturing the advanced membranes required for transportation applications. Figure 9 presents the process diagram for membrane production.

Hollow fibers are produced from a dope of polysulfone dissolved in N,N-dimethyl acetamide (DMAC) to a concentration of $27.5 \mathrm{wt} \%$. The fibers are formed from the dope by extruding through spinnerets. A needle in the middle of the spinneret includes an annular opening through which the spinning dope passes. Water, used as a bore fluid, is directed down the annulus to make the spun fibers hollow. Immediately after extrusion, the fibers are immersed in a water bath to cool and coagulate. The fibers are collected on bobbins and wound separately from each spinneret (which are run 20 in parallel). This is a continuous process; the remaining process steps are completed in batches.

Fibers are collected into hanks consisting of up to 20,000 strands (depending on the desired module diameter) and hung to dry at ambient temperature and humidity.

After drying, an epoxy resin is applied to the ends of the hanks. This process, called potting, collects the hanks into stable fiber bundles. The potted ends are cut to expose the bore of the fibers, and the ends are trimmed with a razor to ensure a smooth face to the bundle and to ensure that the fiber bores are open. A small bit of the length of fiber (typically 1-2 in. per end) is rendered inactive by the application of the potting material.

Potted bundles are inserted into module containers along with O-ring seals at each end to separate the inside (bore) and outside of the fibers. The outside of the fibers is in contact with the space contained by the module casing, analogous to the shell in a shell-and-tube heat exchanger. After sealing the module casing, appropriate fittings are attached to route the air streams to and from the bore- or shell-side of the module, as appropriate.

At this point, the module contains only the porous, polysulfone substrate and possesses no gas-separation ability. The assembled module must still be coated with the active (i.e., nonporous) membrane material - in the cases considered in this study, that material is either CMS-3 or CMS-7.

The module coating is accomplished by dissolving the membrane material (CMS-3 or CMS-7) in an organic solvent (which is not a solvent for polysulfone or other materials used in 

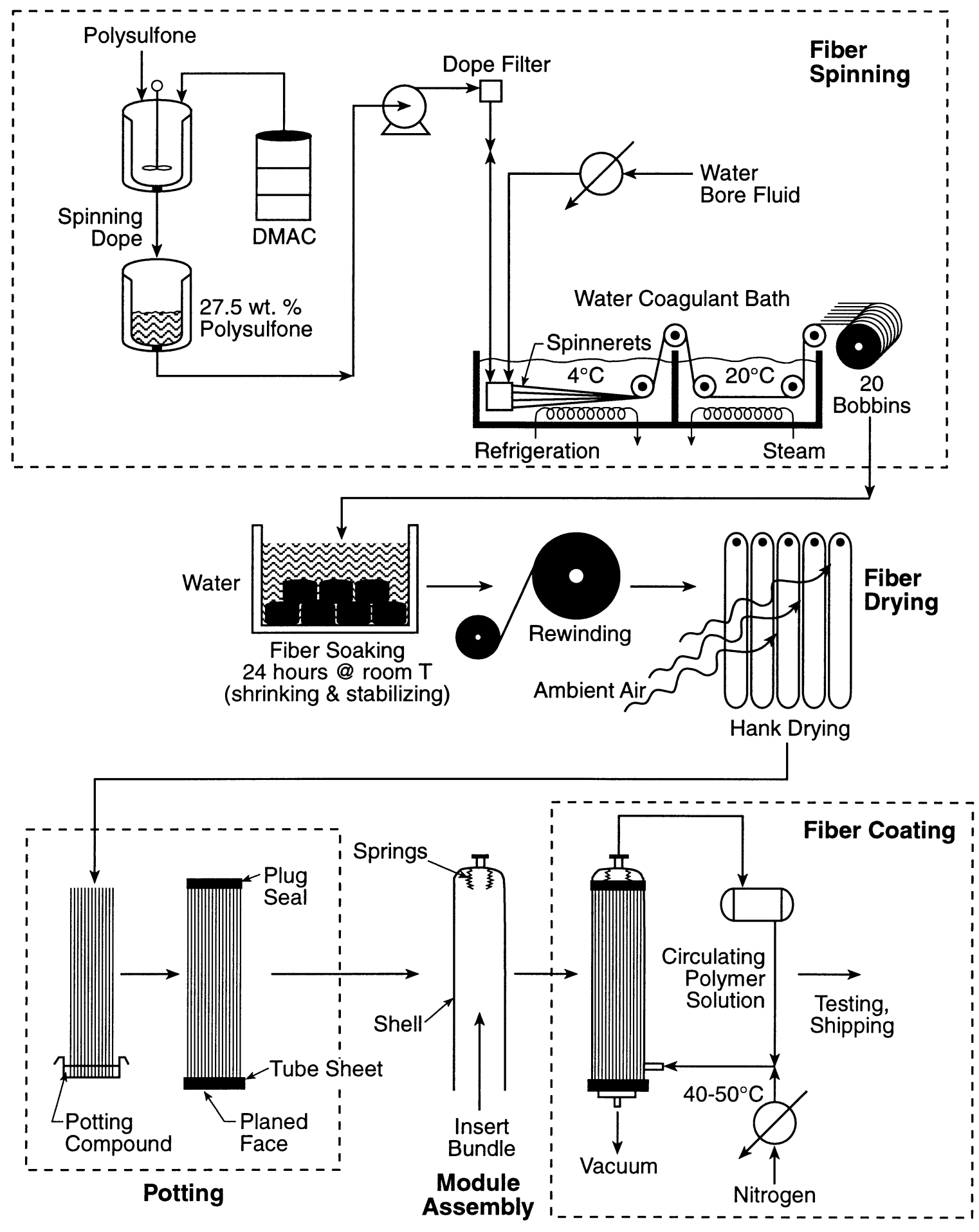

Figure 9 Process Flowchart for Membrane Production 
the module construction, such as rubber for the O-rings) and circulating the solution through the fibers for a period of hours. Once the concentration of the coating solution ceases to change between the inlet and outlet of the module, coating is considered complete. The concentration of membrane material in the coating solution and the choice of solvent appear to be the primary factors that determine eventual membrane thickness.

After membranes have been coated, they are dried by pulling $\mathrm{N}_{2}$ through the membrane for a period of up to $24 \mathrm{~h}$. Then, after initial flow testing with $\mathrm{N}_{2}$, pores and defects are repaired in a post-treatment operation. A pore-seeking compound (such as highly permeable silicone rubber), used in minuscule amounts as a "stop leak," eliminates most Knudson and viscous flow by plugging any holes. Some small amount of active surface area is lost during the pore filling, but selectivity is greatly improved because even a few pores can ruin the separation ability of a membrane by allowing unrestricted mixing of feed gas with permeate through the pores.

\subsection{Membranes for Engine Applications}

The information provided in the preceding sections reveals the need for appropriate membrane intrinsic properties and coating thickness to obtain the smallest possible module size and lowest power demand for membrane engine applications. PDD-TFE copolymers were developed at CMS specifically for vehicular applications. Membrane material is coated by circulating the polymer in a solvent. Table 3 compares CMS membrane properties with those of conventional silicon rubber polymer.

Table 3 Comparison of CMS Polymers with Silicon Rubber

\begin{tabular}{|c|c|c|c|}
\hline Properties & PDD-1 /CMS-3 & PDD-2/CMS-7 & Silicon Rubber \\
\hline \multicolumn{4}{|l|}{ Permeability (barrer) ${ }^{\mathrm{a}}$} \\
\hline Oxygen & 290 & 1,980 & 500 \\
\hline Nitrogen & 116 & 1,070 & 250 \\
\hline Water vapor & 2000 & 4,500 & 5,000 \\
\hline \multicolumn{4}{|l|}{ Selectivity } \\
\hline $\mathrm{O}_{2} / \mathrm{N}_{2}$ & 2.5 & 1.85 & 2.0 \\
\hline Skin thickness $(\mu \mathrm{m})$ & 0.1 & 0.1 & 1.0 \\
\hline Oxygen flux (GPU) ${ }^{b}$ & 1,800 & 9,000 & 500 \\
\hline Upper use temperature $\left({ }^{\circ} \mathrm{C}\right)$ & 160 & 240 & 130 \\
\hline
\end{tabular}

${ }^{\text {a }}$ barrer $=\mathrm{cm}^{3}(\mathrm{STP})-\mathrm{cm} / \mathrm{cm}^{2}-\mathrm{s}-\mathrm{cm} \mathrm{Hg} \times 10^{10}$

${ }^{\mathrm{b}} \mathrm{GPU}$ (gas permeation unit) $=\mathrm{cm}^{3}(\mathrm{STP}) / \mathrm{cm}^{2}-\mathrm{s}-\mathrm{cm} \mathrm{Hg} \times 10^{10}$

Of the two CMS polymers, CMS-7 appears to be more suitable for $\mathrm{O}_{2}$-enrichment applications. Higher permeability at moderate selectivity provides higher permeate recovery $\left(\mathrm{O}_{2}\right.$-enriched airflow) with moderate $\mathrm{O}_{2}$-enrichment level (about 26\%), which is sufficient for current engine applications. CMS-3 is more appropriate for $\mathrm{N}_{2}$-enriched air applications 
because higher selectivity and lower permeability provide higher purity but lower percent recovery of permeate. Consequently, higher $\mathrm{N}_{2}$-enriched airflow (retentate) can be obtained with moderate $\mathrm{N}_{2}$ enrichment (about $83 \%$ ).

A series of prototype modules were developed, using both CMS-3 and CMS-7 materials with different coating thicknesses. In all the prototype modules, membrane area $\left(1.7 \mathrm{~m}^{2}\right)$ was kept constant, with an overall module size of $17.8 \mathrm{~cm}$ (7 in.) in length and $6.4 \mathrm{~cm}(2.5 \mathrm{in}$.) in diameter. The module was packed with a number of hollow fibers $(5,630)$, each measuring $450 \mu \mathrm{m}$ in ID and $720 \mu \mathrm{m}$ in OD. Figure 10 shows a prototype module.
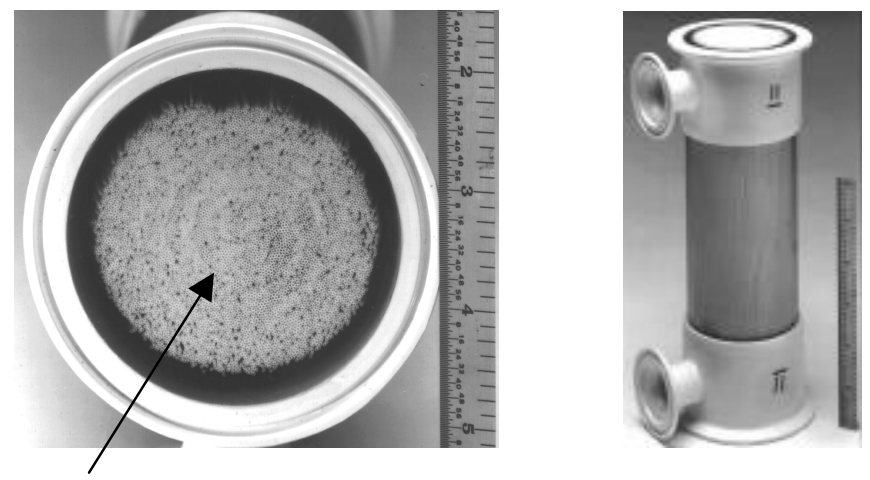

Hollow Fibers

Figure 10 Prototype Membrane Module

During prototype membrane development, the selectivity and flux of modules were obtained on the basis of single-gas tests (feeding first $\mathrm{N}_{2}$ and then $\mathrm{O}_{2}$ to arrive at the selectivity). Subsequent tests were conducted using air (also called "mixed gas"). These test results were reported at the 1998 SAE Congress and Exposition (Poola et al. 1998). Table 4 provides performance data for several prototype modules. From these data, and from additional modeling efforts, we were able to determine appropriate membrane module configurations for the study.

Limited information is available regarding the durability of membrane systems in automotive applications. Because of the sensitivity of membranes to oil contamination, good feed filtration is necessary; a generally well-protected membrane is required. In tests with ambient, unfiltered air, Nemser reports a logarithmic decline in membrane productivity (Nemser 1997). On this basis, the authors have assumed a 50,000-mile membrane service life. 
Table 4 Performance of Prototype Modules Developed at CMS

\begin{tabular}{|c|c|c|c|}
\hline $\begin{array}{l}\text { Membrane } \\
\text { Module No. }\end{array}$ & $\begin{array}{l}\text { Coating Thickness } \\
(\mu \mathrm{m})\end{array}$ & $\begin{array}{c}\mathrm{O}_{2} / \mathrm{N}_{2} \\
\text { Selectivity }\end{array}$ & $\begin{array}{l}\mathrm{N}_{2} \text { Flux } \\
\text { (GPU) }\end{array}$ \\
\hline \multicolumn{4}{|l|}{ CMS-7 } \\
\hline 23 & 0.07 & 1.44 & 15,882 \\
\hline 25 & 0.31 & 1.94 & 3,539 \\
\hline 26 & 0.09 & 1.67 & 12,728 \\
\hline 31 & 0.20 & 1.85 & 5,571 \\
\hline 32 & 0.29 & 1.93 & 3,782 \\
\hline 33 & 0.17 & 1.74 & 6,479 \\
\hline 37 & 0.27 & 1.88 & 4,096 \\
\hline 38 & 0.12 & 1.69 & 9,006 \\
\hline 39 & 0.20 & 1.90 & 4,568 \\
\hline 40 & 0.24 & 1.90 & 4,568 \\
\hline \multicolumn{4}{|l|}{ CMS-3 } \\
\hline A & 0.24 & 2.55 & 492 \\
\hline B & 0.20 & 2.55 & 582 \\
\hline C & 0.26 & 2.56 & 447 \\
\hline D & 0.29 & 2.53 & 406 \\
\hline
\end{tabular}




\section{Section 5 Cost Analysis}

A simple membrane cost model was developed on the basis of current membrane pricing at various production volumes and likely future improvements in the production process. By making thinner membrane coatings, manufacturers can reduce the mass of membrane material required per unit of membrane surface area. Because the cost of the membrane material represents approximately one-quarter of the total cost - overwhelmingly the largest single component of the total module cost - this reduction is important.

A thin membrane coating also is desirable because it would reduce the energy required for gas to flow through the membrane. The challenge is to create a nonporous skin of membrane that is also thin. Just a tiny portion of porous surface area can ruin the separation capability of a membrane by allowing feed-side gas to mix with the exit stream with little relative restriction. CMS has successfully coated its material as thin as $0.07 \mu \mathrm{m}$ and has been making progress in producing even thinner coatings.

For our cost analysis, we used the membrane manufacturing process adapted from the 1991 report by SRI (Schwaar 1991) and the private 1992 DuPont cost study (Lopez 1991) (described in Section 4.4). The capital costs presented in those studies were simply increased to account for inflation. Material and labor costs, and other operating costs, were re-estimated for this study on the basis of a number of sources.

\subsection{Membrane Production Cost}

Table 5 presents the materials and production costs associated with the membrane production process described in Section 4.4. Capital costs were derived from the SRI study and increased to 1995 dollars to account for inflation; other costs were re-estimated on the basis of recent data (Schwaar 1991).

The key feature of the cost analysis is that the membrane material constitutes the largest variable cost - approximately $25 \%$ of the total cost of a module. This finding underscores the importance of reducing membrane thickness.

\subsection{Cases Analyzed}

Five separate cases were defined for the analysis. Each case was selected as a representative application of a membrane system in a diesel vehicle. For each case, the vehicle engine targeted was a 90-hp TDI diesel engine. This engine was selected because it is a modern production engine for which data are available, and it is typical of the type of engine that might be used to power a PNGV vehicle. The engine consumes 100.8 standard cubic feet 
Table 5 Process-Based Cost of Membrane Manufacture a,b

\begin{tabular}{|c|c|c|c|c|c|}
\hline Variable & $\begin{array}{l}\text { Amount } \\
\text { Required }\end{array}$ & Cost & $\begin{array}{l}\text { Cost per } \\
\text { Year (\$) }\end{array}$ & $\begin{array}{c}\text { Cost per } \\
\text { Square Foot } \\
\text { (\$) }\end{array}$ & $\begin{array}{c}\text { Cost per } \\
\text { Module (\$) }\end{array}$ \\
\hline \multicolumn{6}{|l|}{ Materials } \\
\hline $\begin{array}{l}\text { Polysulfone (for fiber } \\
\text { supports) }\end{array}$ & $9,257 \mathrm{lb} / \mathrm{yr}$ & $\$ 3.92 / \mathrm{lb}$ & 36,287 & 0.04 & 3.63 \\
\hline $\begin{array}{l}\text { Dimethyl acetamide } \\
\text { solvent }\end{array}$ & $24,400 \mathrm{lb} / \mathrm{yr}$ & $\$ 0.92 / \mathrm{lb}$ & 22,448 & 0.02 & 2.24 \\
\hline Waste solvent disposal & $24,400 \mathrm{lb} / \mathrm{yr}$ & $\$ 0.50 / \mathrm{lb}$ & 12,200 & 0.01 & 1.22 \\
\hline Epon 826 resin & $0.7 \mathrm{lb} /$ module & $\$ 1.31 / \mathrm{lb}$ & 9,301 & 0.01 & 0.93 \\
\hline $\begin{array}{l}\text { Neopentyl glycol } \\
\text { diglycidyl ether }\end{array}$ & $0.1 \mathrm{lb} /$ module & $\$ 1.10 / \mathrm{lb}$ & 880 & 0.00 & 0.09 \\
\hline Aluminum powder & $0.5 \mathrm{lb} /$ module & $\$ 4.65 / \mathrm{lb}$ & 24,180 & 0.02 & 2.42 \\
\hline Tubesheet curing agents & $0.1 \mathrm{lb} /$ module & $\$ 9.00 / \mathrm{lb}$ & 5,760 & 0.01 & 0.58 \\
\hline Defect repair solution & $0.4 \mathrm{lb} /$ module & $\$ 1.50 / \mathrm{lb}$ & 6,000 & 0.01 & 0.06 \\
\hline $\begin{array}{l}\text { Membrane coating } \\
\text { material }\end{array}$ & $\begin{array}{l}10,000 \\
\text { modules/yr }\end{array}$ & $\$ 36.00 /$ module & 360,000 & 0.36 & 36.00 \\
\hline $\begin{array}{l}\text { Low-pressure shells } \\
\text { (prefab, purchased) }\end{array}$ & $\begin{array}{l}10,000 \\
\text { modules/yr }\end{array}$ & $\$ 10.00 /$ module & 100,000 & 0.10 & 10.00 \\
\hline \multicolumn{6}{|l|}{ Operating Costs } \\
\hline $\begin{array}{l}\text { Utilities (steam, } \mathrm{H}_{2} \mathrm{O}, \mathrm{N}_{2} \text {, } \\
\text { refrigeration) }\end{array}$ & & & 20,000 & 0.02 & 2.00 \\
\hline $\begin{array}{l}\text { Maintenance labor and } \\
\text { materials }\end{array}$ & & & 42,000 & 0.04 & 4.20 \\
\hline $\begin{array}{l}\text { Labor (2 operators at } \\
\$ 25 / \mathrm{h}, 2,000 \mathrm{~h} / \mathrm{yr})\end{array}$ & & & 100,000 & 0.10 & 10.00 \\
\hline Testing laboratory & & & 120,000 & 0.12 & 12.00 \\
\hline $\begin{array}{l}\text { Plant overhead ( } 80 \% \text { of } \\
\text { total labor) }\end{array}$ & & & 115,400 & 0.12 & 11.54 \\
\hline $\begin{array}{l}\text { Depreciation, taxes, } \\
\text { insurance }\end{array}$ & & & 84,000 & 0.08 & 8.40 \\
\hline Total Operating Costs & & & $1,058,456$ & 1.06 & 105.85 \\
\hline $\begin{array}{l}\text { Capital Recovery (5 yr at } \\
10 \%)\end{array}$ & & & 250,608 & 0.25 & 25.06 \\
\hline $\begin{array}{l}\text { Total Cost (capital and } \\
\text { operating) }\end{array}$ & & & $1,309,064$ & 1.31 & 130.91 \\
\hline
\end{tabular}

a Sources: Nemser 1997; Schwaar 1991; Lopez 1991.

b The costs presented are based on the following assumptions: Hollow-fiber material used is polysulfone; hollowfiber dimensions are 1,050 $\mu \mathrm{m}$ OD, $850 \mu \mathrm{m}$ ID; annual plant capacity is 10,000 modules, $100 \mathrm{ft}^{2} /$ module; and the estimated capital cost for the plant is $\$ 950,000$ (in 1995 dollars). 
per minute $(\mathrm{scfm})$ of intake air at maximum power (i.e., engine speed of 4,000 rotations per minute $[\mathrm{rpm}]$ ) and the specified maximum boost available from the turbocharger (i.e., 0.8 bar).

Membrane systems appropriate for each case were designed with the help of a DuPont computer model. This model - a multidimensional, mass- and momentum-transfer model — is used commercially by DuPont for membrane design. It is generic and is not biased in favor of a specific membrane material. Membrane properties are exogenous inputs. Argonne had access to the model through CMS.

The authors specified the membrane module characteristics sought, fixed case-dependent variables, and selected module sizes based on off-line calculations of approximate module geometry. The model was then run to produce an appropriate membrane and determine flows and pressures. The authors calculated the work requirement based on the expected duty cycle of the membrane (which, like the membrane itself, differed for each case) and sized the auxiliary equipment required for each case. We calculated the energy required to deliver the air stream of interest in each case as isentropic work times an efficiency factor $(\eta)$. For pumps and compressors, $\eta$ was assumed to be 0.7 ; for blowers, $\eta$ was assumed to be 0.8 .

After membrane systems were defined, the cost of each membrane module was estimated on the basis of process-based cost (in $\$ / \mathrm{ft}^{2}$ ), as described above. A current cost curve, based on the square-footage of membrane required, was developed from commercial data (Nemser 1997). The process-based analysis agreed well with the price-based curve, producing a point that lies quite near the curve at the production volume assumed for the process analysis $\left(1,000,000 \mathrm{ft}^{2}\right.$ membrane/year).

Future costs for the membrane systems were estimated on the basis of assumed reductions in membrane coating thickness (which reduces costs because less material is required to make a given surface area of pore-free membrane). Cost reductions of one-sixth and one-third of current costs were assumed. The three resulting cost curves are presented in Figure 11.

Historical reductions in the cost of membrane production have been significant. L'Air Liquide reported a decline in the cost of $\mathrm{N}_{2}$-enrichment membrane production from $\$ 5 / \mathrm{ft}^{2}$ to $\$ 1 / \mathrm{ft}^{2}$ between 1990 and 1996 (Roman 1996). Advances in fiber-spinning and processing technology allowed manufacturers to mass-produce modules and fabricate them while using less membrane material — which significantly reduced costs.

Advances in membrane production processes are the primary factors in reducing the cost of mass-produced membrane systems. Auxiliary equipment - filters, pumps, blowers, hoses, and (in some cases) a plenum - are already available in large quantities and are unlikely to benefit from economies of scale or from technology improvement. We have assumed that the auxiliary equipment is mature. The CMS membrane materials appear to have the potential to be coated in thinner layers, comparable to those achieved with commercial membrane materials. On the basis of this assumption, our future cost-reduction estimates of one-sixth and one-third for the membrane material are quite conservative. 


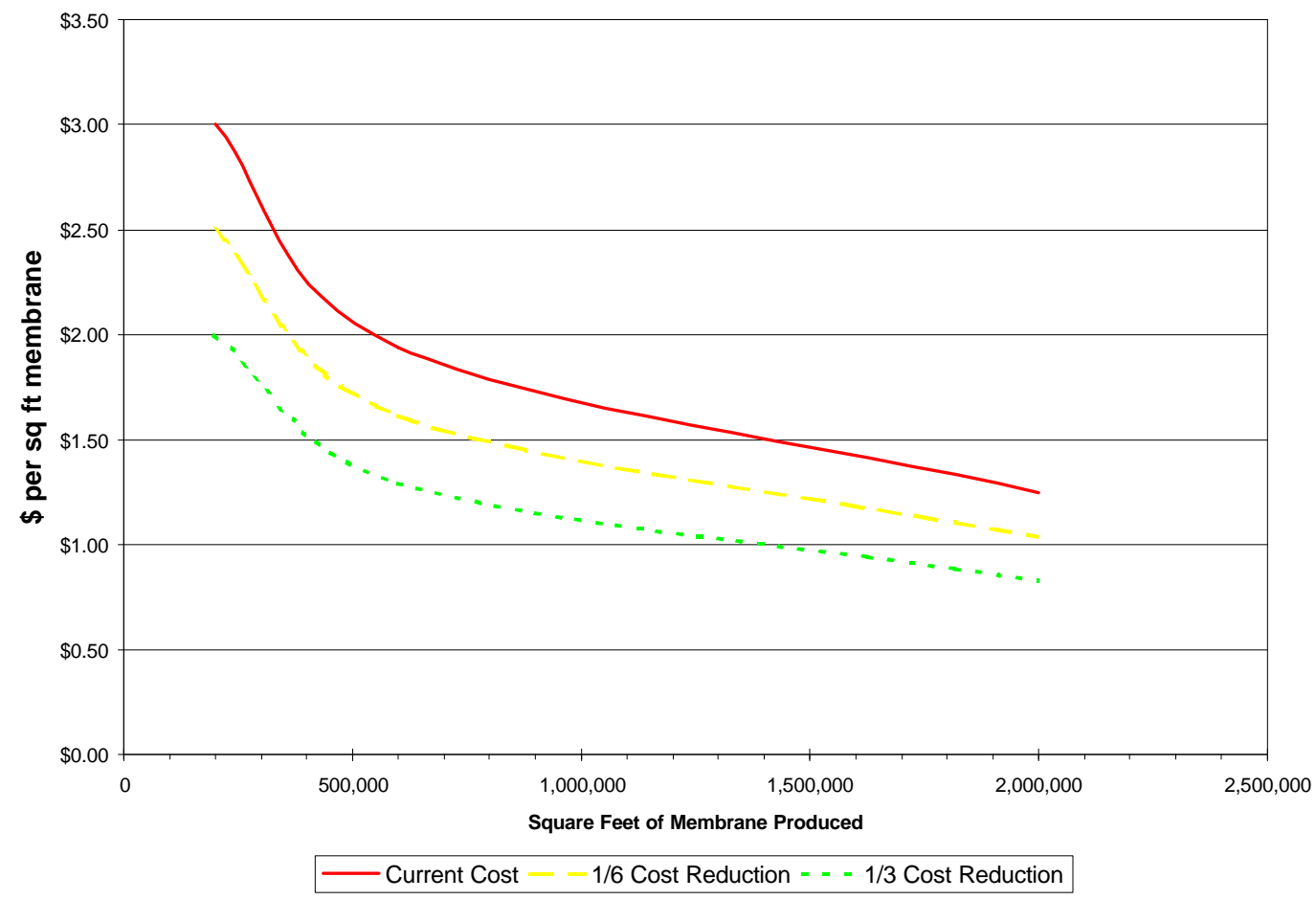

Figure 11 Current and Projected Membrane Cost as a Function of Surface Area Manufactured

During the decade in which Argonne has been evaluating $\mathrm{O}_{2}$-enrichment membranes, the productivity of membranes has increased markedly. Figure 12 illustrates this trend by showing module volume per unit flow rate of tested $\mathrm{O}_{2}$-enrichment membranes since 1989 . By 1999, we project $1.5 \mathrm{in} .{ }^{3} / \mathrm{scfm}$ will be achieved.

\subsection{Evaluation of the Cases}

The cases defined in Table 1 were selected to address specific emissions problems or performance issues that affect light-duty CIDI engines. Figures 13-17 and Tables 6-10 summarize the results for each of the cases. The figures present cost curves for the systems in each case, developed at the three potential membrane price levels. The tables summarize the characteristics of the membrane for each case and those of the competing technology.

The expected duty cycle for the membrane system in each case differed, depending on the application of the system. For lack of a definitive driving cycle, portions of the FTP were used to estimate the amount of time each module would typically be operating. Use of the FTP affected the parasitic load (or power benefit) of the system as an operating cost (or benefit). 


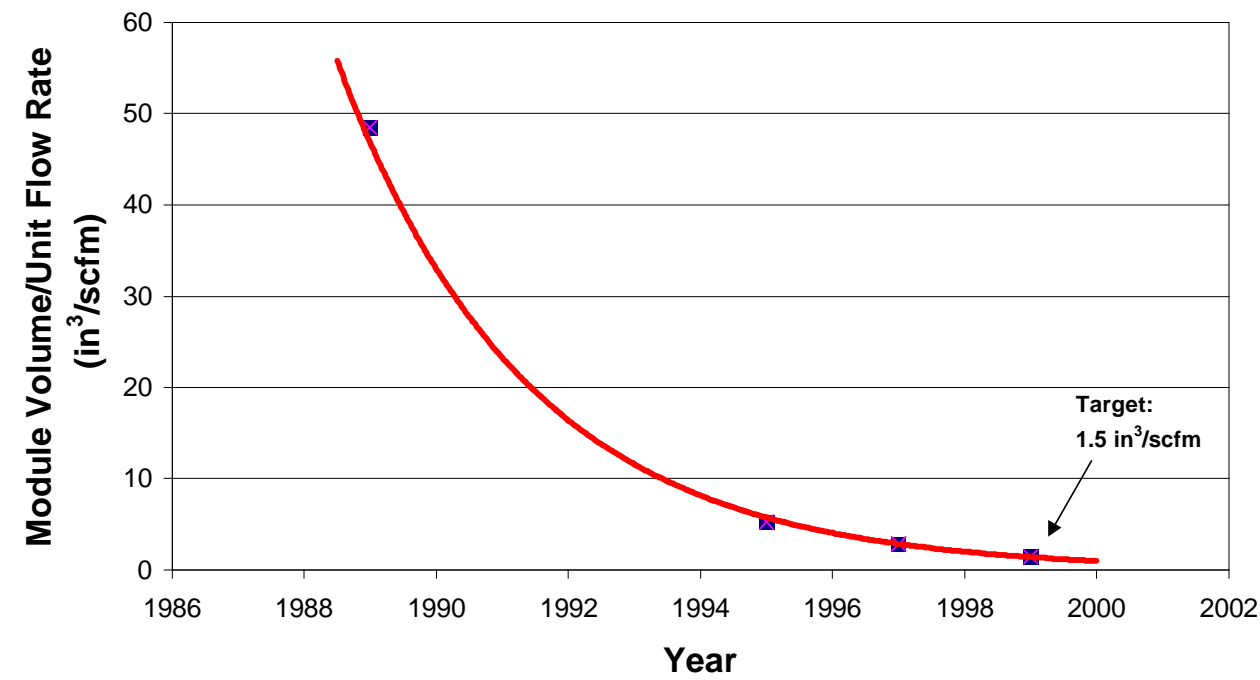

Figure 12 Membrane Size vs. Time

\subsection{1 $\mathrm{NO}_{\mathrm{x}}$ Control Case}

The $\mathrm{NO}_{\mathrm{x}}$ control case (using $\mathrm{N}_{2}$-enriched air in the intake on demand) is the simplest of the cases analyzed. Minimal auxiliary equipment is required because operation is in pressure mode and driving force is provided by the turbocharger. Thus, in this case, the auxiliary equipment was limited to fittings, tubing, and valves. This system was compared to an advanced lean- $\mathrm{NO}_{\mathrm{x}}$ catalyst ( which as yet does not exist) along with EGR (which, as noted above, introduces hot gas and deleterious material into the cylinders if unfiltered $-\mathrm{N}_{2}$-enriched air does not). Table 6 summarizes the results of the $\mathrm{NO}_{\mathrm{x}}$ control case, and Figure 13 presents the resulting cost curve for the system.

Table 6 Results: $\mathrm{NO}_{\mathrm{x}}$ Control Case

\begin{tabular}{|ll|}
\hline \multicolumn{1}{|c|}{ Membrane System } & \multicolumn{1}{c|}{ Competing Technology } \\
\hline $100 \mathrm{cfm}$ of $81 \% \mathrm{~N}_{2}$-Enriched Air & Lean- $\mathrm{NO}_{\mathrm{x}}$ Catalyst, SCR ${ }^{\mathrm{a}}$ Type + EGR \\
- Cost: $\$ 75-110$ & - Cost: $\$ 300+$ maintenance \\
- Parasitic power: $2.2 \mathrm{hp}$ while in use & - Parasitic power: added backpressure and \\
- Fuel economy: Negligible penalty; expected to be & electricity for catalyst lightoff \\
used $25 \%$ of the time, on the basis of & - Fuel economy: penalty for use of diesel fuel \\
accelerations and high load portions of FTP & as reductant; requires premium fuel \\
\hline
\end{tabular}

a SCR = selective catalytic reduction. 


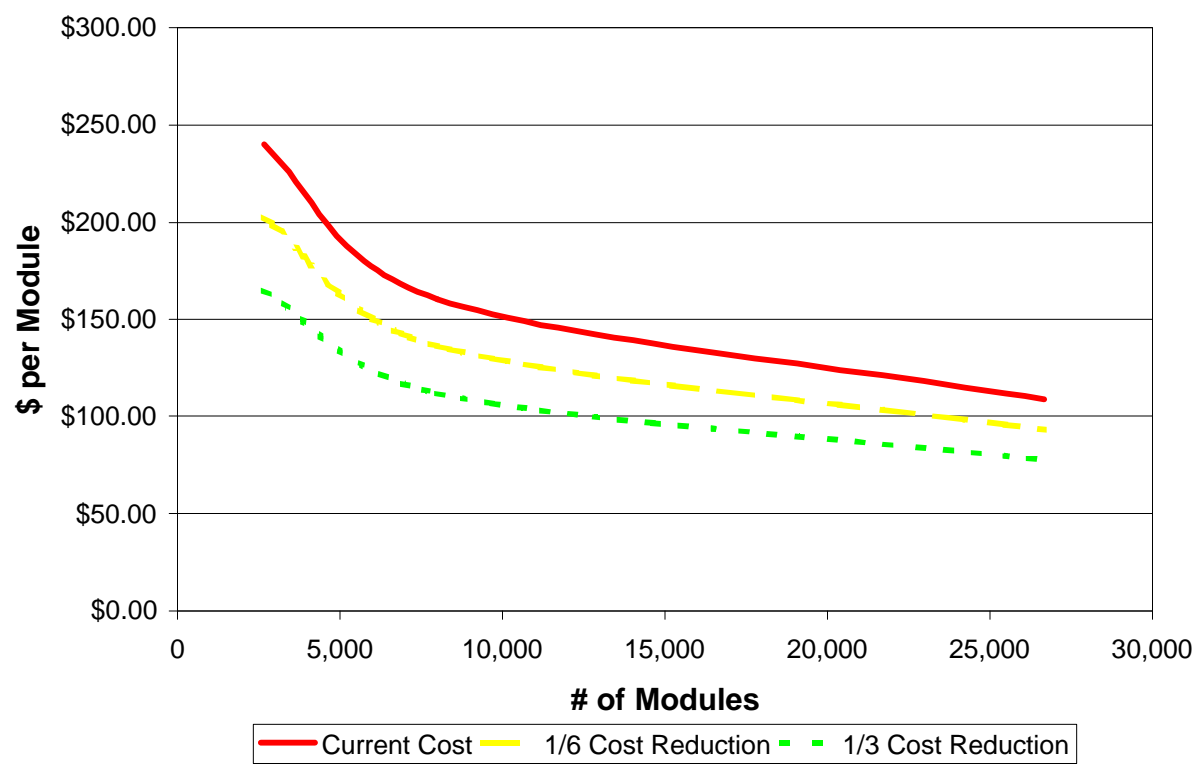

Figure $13 \mathrm{~N}_{2}$-Enrichment Module Cost Curves

The per-module system cost of $10,000 \mathrm{~N}_{2}$-enrichment modules would be approximately $\$ 160$ for the current-price case, $\$ 130$ for the 1/6 cost-reduction case, and $\$ 110$ for the $1 / 3$ costreduction case.

\subsubsection{PM Control Case}

The PM control case uses $\mathrm{O}_{2}$-enriched air to help reduce $\mathrm{PM}$ emissions for diesels and may allow the diesel to meet the PNGV research goal of $0.01 \mathrm{~g} / \mathrm{mi} \mathrm{PM}$ - a level of control not achievable with any current technology. For vacuum-mode operation, which is necessary in this case, a vacuum pump is required. A particulate trap could be designed to control PM to this level but would cause significant backpressure and probably durability problems. Table 7 and Figure 14 present the results and cost curves, respectively, for the PM control case.

Table 7 Results: PM Control Case

\begin{tabular}{|c|c|}
\hline Membrane System & Competing Technology \\
\hline $\begin{array}{ll} & 100 \mathrm{cfm} \text { of } 23 \% \mathrm{O}_{2} \text {-Enriched Air } \\
\text { - } & \text { Cost: } \$ 149-200 \\
\text { - } & \text { Parasitic power: } 6.4 \text { hp while in use } \\
\text { - } & \text { Power regained by increase in engine power } \\
\text { - } & \text { Used under high-PM conditions ( } 10 \% \text { of the } \\
& \text { time under the FTP) }\end{array}$ & $\begin{array}{l}\text { Particulate Trap with Fuel Additives } \\
\text { - Cost: } \$ 200+\$ 0.02 / \text { gal for additives } \\
\text { - Parasitic power: Significant increase caused by } \\
\text { backpressure increase and trap regeneration } \\
\text { - Fuel economy: unknown penalty } \\
\text { - Traps generally have durability problems }\end{array}$ \\
\hline
\end{tabular}




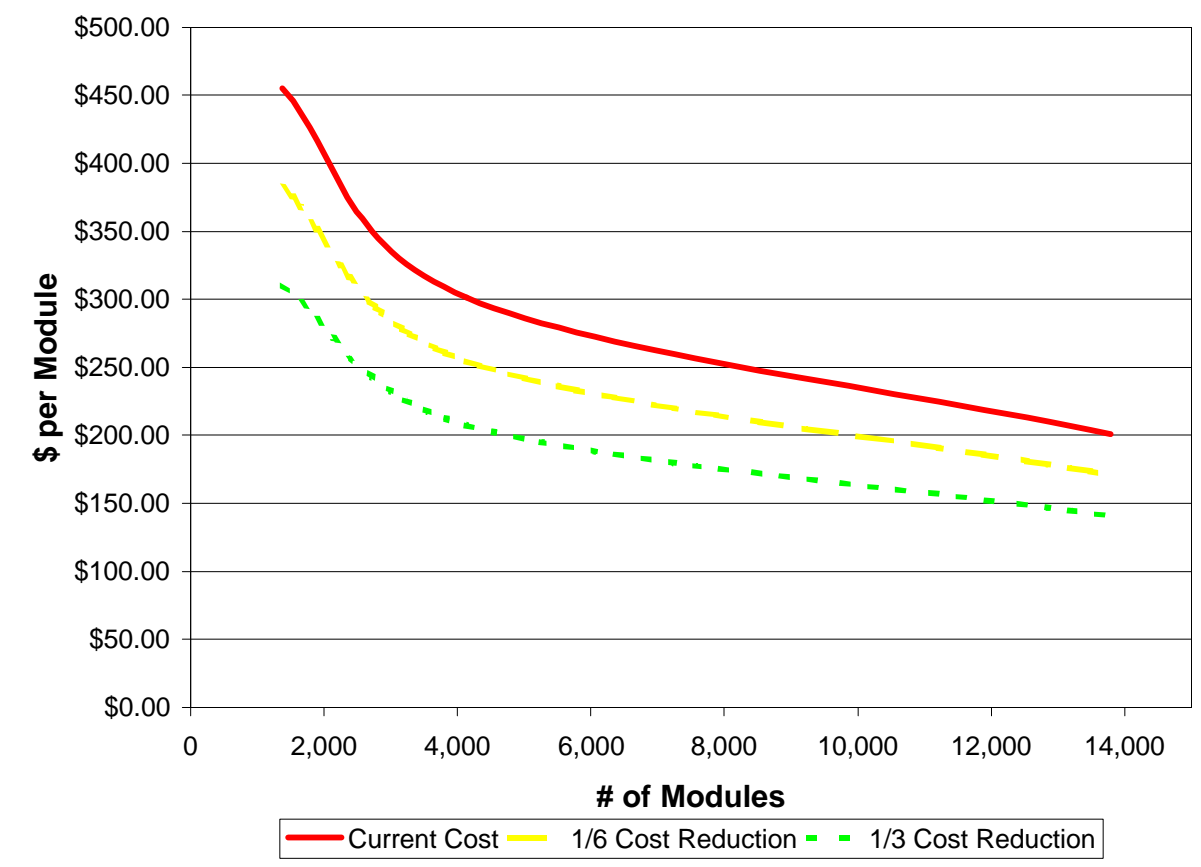

Figure $14 \quad \mathrm{O}_{2}$-Enrichment Module Cost Curves

The per-module system cost of $10,000 \mathrm{O}_{2}$-enrichment modules would be approximately $\$ 240$ for the current-price case, $\$ 205$ for the 1/6 cost-reduction case, and $\$ 160$ for the $1 / 3$ costreduction case.

\subsubsection{Variable Air Composition Case}

The variable air composition case combines elements of both the $\mathrm{PM}$ and $\mathrm{NO}_{\mathrm{x}}$ control cases. This case has the greatest potential to allow the CIDI engine to meet both the $\mathrm{NO}_{\mathrm{x}}$ and particulate standards by virtue of controlled introduction of $\mathrm{N}_{2}$-enriched or $\mathrm{O}_{2}$-enriched air into the cylinder as required by the driving cycle (determined by the speed and load of the engine).

This case is also the most complicated system, as indicated in Figure 3. We do not, at this point, have sufficient data on the transient response of the membrane to make a quantitative assessment of the system's effectiveness. The variable air composition system is compared to a combination of a lean $\mathrm{NO}_{\mathrm{x}}$ catalyst and a particulate trap - simply combining the technologies of the first two cases. Table 8 and Figure 15 present the results and cost curves, respectively, for the variable air composition case. 
Table 8 Results: Variable Air Composition Case

\begin{tabular}{|ll|}
\hline \multicolumn{1}{|c|}{ Membrane System } & \multicolumn{1}{c|}{ Competing Technology } \\
\hline $100 \mathrm{cfm}$ of $23 \% \mathrm{O}_{2}$ - or $81 \% \mathrm{~N}_{2}$-Enriched Air & Lean- $\mathrm{NO}_{\mathrm{x}}$ Catalyst, EGR \& Particulate Trap \\
- Cost: $\$ 190-265$ & Cost: $~ \$ 500+$ maintenance + fuel additive \\
- Parasitic power: $6.4 \mathrm{hp}$ while in use & cost \\
- Fuel economy: depends on duty cycle & - Parasitic power: significant primarily because \\
& of backpressure and trap regeneration \\
& - Fuel economy: unknown penalty \\
\hline
\end{tabular}

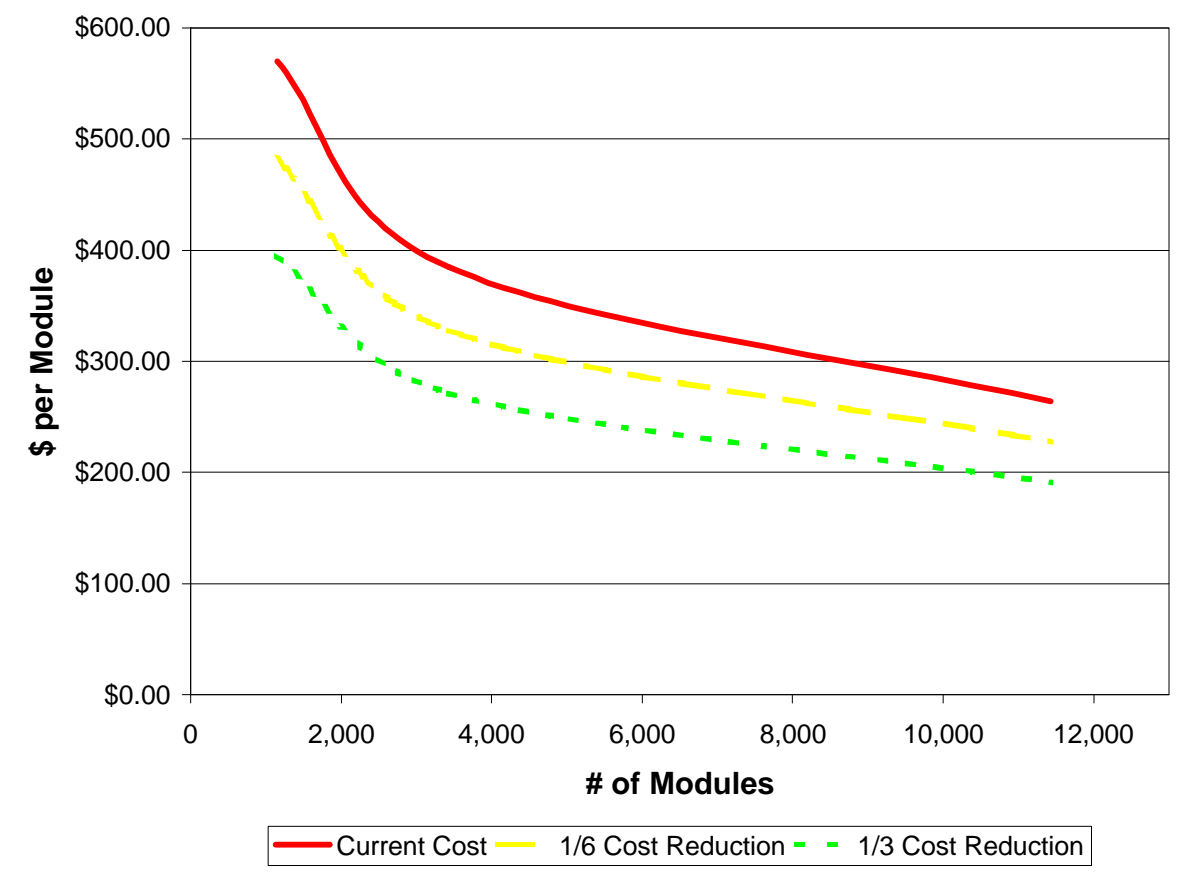

Figure 15 Variable Air Module Cost Curves

The per-module system cost of 10,000 variable air-composition modules would be approximately $\$ 290$ for the current-price case, $\$ 250$ for the $1 / 6$ cost-reduction case, and $\$ 215$ for the $1 / 3$ cost-reduction case.

\subsubsection{Power-Enhancement Case}

The power-enhancement case is a variation of the $\mathrm{PM}$ control case; 25\% $\mathrm{O}_{2}$ rather than $23 \% \mathrm{O}_{2}$ is used in this case. While there would be a net increase in specific power for the PM control case, it would be moderate relative to the power-enhancement case. Earlier Argonne studies indicate a net increase of 10-20\% in engine power output for the power-enhancement case (Sekar et al. 1990; Poola et al. 1996). This estimate is het'in the sense that power to operate the membrane system has been deducted from the total (gross) engine power output. As 
an $\mathrm{O}_{2}$-enrichment case, vacuum-mode operation is anticipated and a suitable vacuum pump would be required. Table 9 and Figure 16 present the results and cost curves, respectively, for the powerenhancement case.

Table 9 Results: Power-Enhancement Case

\begin{tabular}{|ll|}
\multicolumn{1}{|c|}{ Membrane System } & \multicolumn{1}{c|}{ Competing Technology } \\
\hline & \\
$100 \mathrm{cfm}$ of $25 \% \mathrm{O}_{2}$-Enriched Air & \multicolumn{1}{c}{ Larger Engine or Turbocharger } \\
- Cost: $\$ 180-270$ & Cost: cost of a larger engine or turbocharger \\
- Parasitic power: $7.7 \mathrm{hp}$ (more than offset & - Parasitic power: N/A \\
by net power increase) & - Specific weight target $(>45 \mathrm{~kW} / \mathrm{L}$ ) is difficult to \\
- Increase in net power by $10-20 \%$, & attain \\
as needed & \\
\hline
\end{tabular}

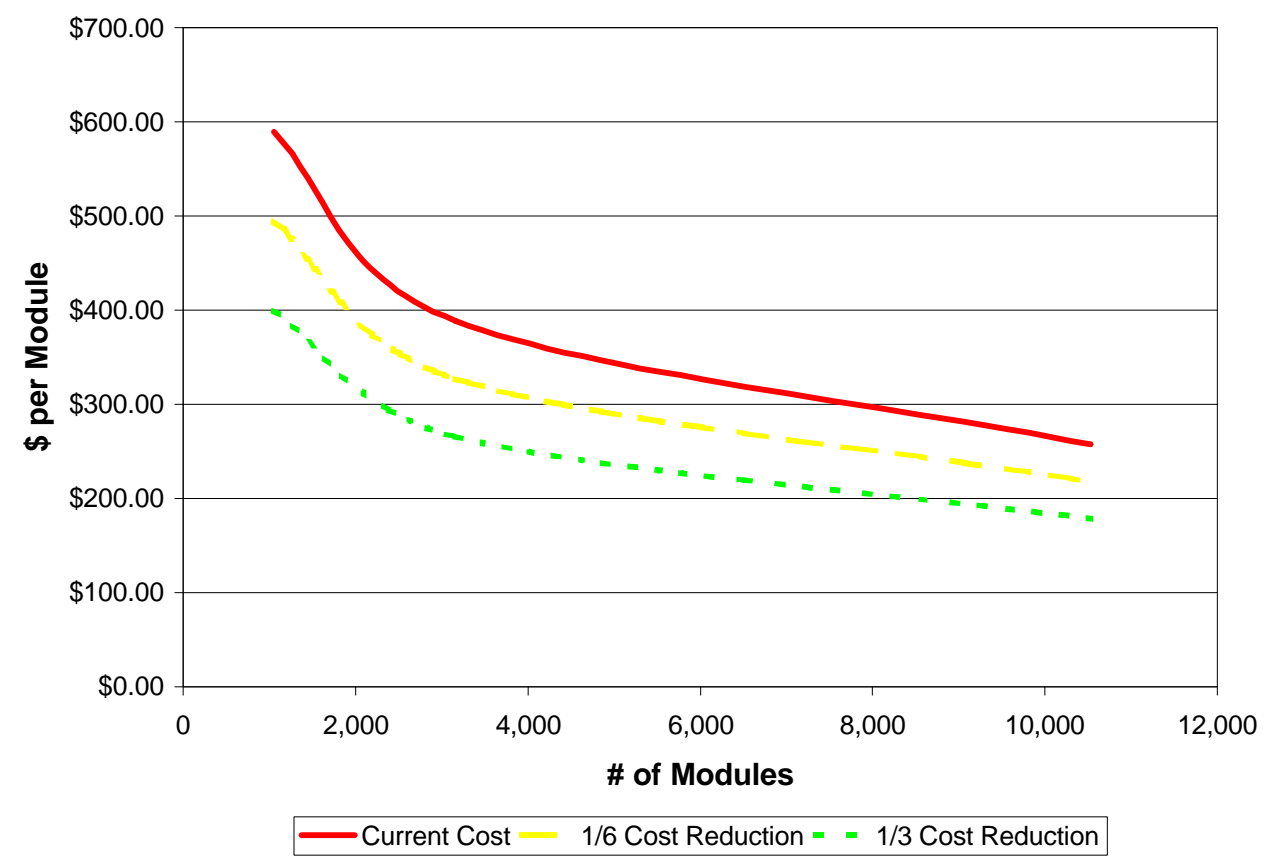

Figure 16 Power-Enhancement $\mathrm{O}_{2}$ Module Cost Curves

The per-module system cost of 10,000 power-enhancement modules would be approximately $\$ 280$ for the current-price case, $\$ 240$ for the 1/6 cost-reduction case, and $\$ 190$ for the $1 / 3$ costreduction case. 


\subsubsection{Late-Cycle $\mathrm{O}_{2}$ Injection Case}

The final case is a membrane system appropriate for use with Argonnes concept of latecycle $\mathrm{O}_{2}$ injection, described in Section 2. The flow requirements for this application are quite low $(10 \mathrm{scfm})$, but the $\mathrm{O}_{2}$ level desired is relatively high $\left(30 \% \mathrm{O}_{2}\right)$. After the generation of the $\mathrm{O}_{2}$-enriched permeate in this case, the stream would be highly pressurized to allow it to be injected directly into the cylinder, after top dead center (TDC), to help oxidize particulates.

This case, the least developed of those evaluated, is derived from a concept that is untested, although Argonne has applied for a patent. Auxiliary equipment includes a compressor to generate high-pressure feed plus modifications to the engine to allow injection of $\mathrm{O}_{2}$-enriched air into the cylinder. Costs estimated here do not include engine modifications. Table 10 and Figure 17 present the results and cost curves, respectively, for the late-cycle $\mathrm{O}_{2}$ injection case.

\section{Table 10 Results: Late-Cycle $\mathrm{O}_{2}$ Injection Case}

\begin{tabular}{|cc|}
\hline \multicolumn{1}{|c|}{ Membrane System } & Competing Technology \\
\hline $10 \mathrm{cfm}$ of $30 \% \mathrm{O}_{2}$-Enriched Air & Particulate Trap + Fuel Additives \\
- Cost: $\$ 100-\$ 120$ & - Cost: $\$ 200+\$ 0.02 /$ gal for additives \\
- Parasitic power: $5.0 \mathrm{hp}$ while operating & - Parasitic power: significant increase caused by \\
- Fuel economy: unknown effect & backpressure increase and trap regeneration \\
- Potential for in-cylinder PM control & - Fuel economy: unknown penalty \\
& - Traps generally have durability problems \\
\hline
\end{tabular}

The per-module system cost of 10,000 late-cycle $\mathrm{O}_{2}$-injection modules would be approximately $\$ 120$ for the current-price case, $\$ 110$ for the 1/6 cost-reduction case, and $\$ 105$ for the $1 / 3$ cost-reduction case (not including the cost to modify the engine to allow injection of air directly to the cylinder).

\subsection{Conclusions}

The membrane systems analyzed compete well with the alternative technologies. Most of these alternatives, at this point, do not exist in the market and therefore are on relatively equal footing with developmental membrane systems. Table 11 summarizes the cases analyzed in terms of cost, size (diameter ऋength), power requirements, and benefits of each case. 


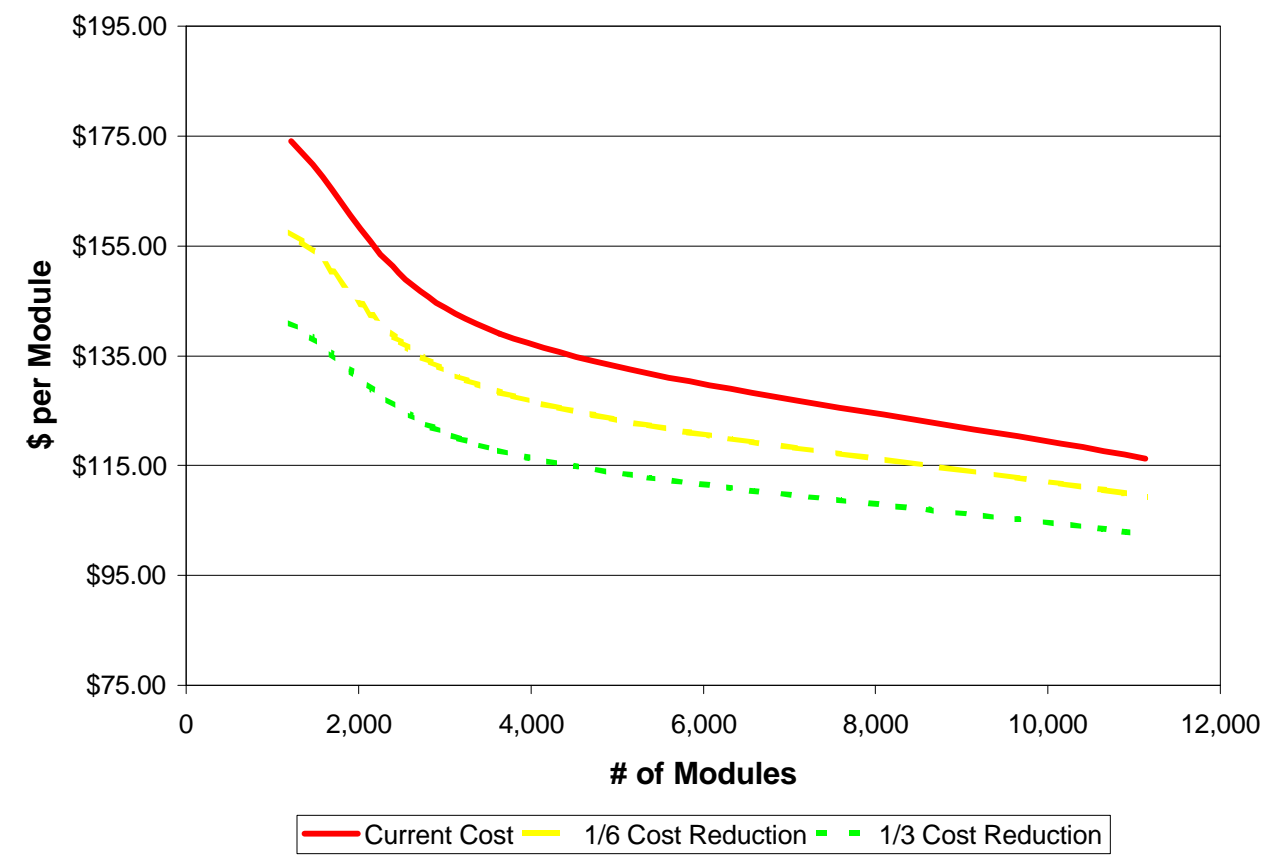

Figure 17 Late-Cycle $\mathrm{O}_{2}$ Injection Module Cost Curves

Table 11 Summary of Cases

\begin{tabular}{|c|c|c|c|c|}
\hline $\begin{array}{c}\text { Case } \\
\text { (module size) }\end{array}$ & $\begin{array}{l}\text { Current Prototype } \\
\text { Cost (\$/module) }\end{array}$ & $\begin{array}{l}\text { Future, Mass- } \\
\text { Produced Cost } \\
\text { (\$/module) }\end{array}$ & $\begin{array}{c}\text { Power } \\
\text { Required } \\
\text { (hp) }\end{array}$ & Potential Benefit \\
\hline $\begin{array}{l}\mathrm{NO}_{x} \text { Control } \\
(13 \text { in. } \times 5 \text { in. })\end{array}$ & 240 & $75-110$ & $2.2^{a}$ & $\begin{array}{l}\text { Less expensive than } \mathrm{NO}_{x} \\
\text { catalyst }\end{array}$ \\
\hline $\begin{array}{l}\text { PM Control } \\
\text { (18 in. } \times 8 \text { in.) }\end{array}$ & 455 & $140-200$ & 6.4 & $\begin{array}{l}\text { Reach PNGV target of } 0.01 \\
\mathrm{~g} / \mathrm{mi} \text { PM }\end{array}$ \\
\hline $\begin{array}{l}\text { Variable Air } \\
\text { (15 in. } \times 8 \text { in.) }\end{array}$ & 570 & 190-265 & 5.8 & $\begin{array}{l}\text { Low duty-cycle emissions of } \\
\mathrm{PM} \text { and } \mathrm{NO}_{\mathrm{x}}\end{array}$ \\
\hline $\begin{array}{l}\text { Power Enhancement } \\
\text { (18 in. } \times 9 \text { in.) }\end{array}$ & 590 & $180-260$ & 7.7 & $\begin{array}{l}10-20 \% \text { net power increase } \\
\text { on demand }\end{array}$ \\
\hline $\begin{array}{l}\text { Late-Cycle } \mathrm{O}_{2} \\
(12 \text { in. } \times 4 \text { in.) }\end{array}$ & 175 & $100-120$ & 5.0 & $\begin{array}{l}\text { Control of PM to } \\
0.01 \mathrm{~g} / \mathrm{mi}\end{array}$ \\
\hline
\end{tabular}

a Additional power is required for the $\mathrm{N}_{2}$-product membrane. Power can be recovered from the engine in other cases (depending on duty cycle). 


\section{Section 6 References}

Anand, J.N., S.E. Bales, D.C. Feay, and T.O. Jeanes, 1989, "Tetrabromo Bisphenol-Based Polycarbonate Membranes and Method of Using," U.S. Patent 4,840,646.

Arcoumanis, C., A. Nagwaney, W. Hentschel, and S. Röpke, 1995, Effect of EGR on Spray Development, Combustion and Emissions in a 1.9-L Direct-Injection Diesel Engine, SAE Paper 952356.

Baker, R.H., E.L. Cussler, W. Eykamp, W.J. Koros, R.L. Riley, and H. Strathmann, 1990, Membrane Separation Systems: A Research Needs Assessment Final Report, U.S. Department of Energy, Vol. 2, DOE/ER/30133-H1.

Bowen, C.E., G.T. Reader, and I.J. Potter, 1996, $N O_{x}$ and Marine Diesel Design and Operation, SAE Paper 960777.

Brandup, J., and E.H. Immergut, 1975, Polymer Handbook (Second Edition), John Wiley and Sons, New York, N.Y.

Callaghan, K., S. Nemser, R.B. Poola, K.C. Stork, R.R. Sekar, and W. Johanson, 1998, Nitrogen Enriched Intake Air for the Reduction of $N O_{x}$ in Diesel Engines, SAE Paper 981077.

Dürnholz, M., G. Eifler, and H. Endres, 1992, Exhaust Gas Recirculation - A Measure to Reduce Exhaust Emissions of DI Diesel Engine, SAE Paper 920725.

Environex, Inc., 1997, Diesel Emission Control Options, Wayne, Penn.

Ghojel, J., J.C. Hilliard, and J.A. Levendis, 1983, Effect of Oxygen-Enrichment on the Performance and Emissions of I.D.I. Diesel Engines, SAE Paper 830245.

Gollan, A.Z., and M.H. Kleper, 1985, Research into an Asymmetric Membrane Hollow Fibre Device for Oxygen-Enriched Air Production, Phase II Report, DOE Contract DE-AC07-83 ID 12429, Dec.

Henis, J., and M. Tripodi, 1980, "Multicomponent Membranes for Gas Separations," U.S. Patent No. 4230463.

Hilliard, J.C., and F.J. Weinberg, 1976, "Effect of Nitrogen-Containing Plasmas on Stability, NO Formation and Sooting of Flames," Nature (259):556-557.

Iida, N., Y. Suzuki, G.T. Sato, and T. Sawada, 1986, Effects of Intake Oxygen Concentration on the Characteristics of Particulate Emissions from D.I. Diesel Engine, SAE Paper 861233. 
Karim, G.A., and G. Ward, 1968, The Examination of the Combustion Processes in a CompressionIgnition Engine by Changing the Partial Pressure of Oxygen in the Intake Charge, SAE Paper 680767.

Koros, W.J., and R.T. Chern, 1987, Handbook of Separation Process Technology, John Wiley and Sons, New York, N.Y.

Ladommatos, N., R. Balian, R. Horrocks, and L. Cooper, 1996, The Effect of Exhaust Gas Recirculation on Combustion and $\mathrm{NO}_{x}$ Emissions in a High-Speed Direct-Injection Diesel Engine, SAE Paper 960840.

Li, J., J.O. Chae, S.B. Park, H.J. Paik, J.K. Park, Y.S. Jeong, S.M. Lee, and Y.J. Choi, 1997, Effect of Intake Composition on Combustion and Emission Characteristics of DI Diesel Engine at High Intake Pressure, SAE Paper 970322.

Lopez, R.E., 1991, Engineering Evaluation for $\mathrm{O}_{2}$ Enrichment Gas Permeators, Du Pont Engineering, Newark, Del.

Morimune, T., and Y. Ejiri, 1994, "Removal of Nitrogen Oxides Contained in Combustion Exhaust Gas by Nitrogen Plasma Injection," JSME International Journal, Series B, 37(4):945-950.

Nagai, T., H. Endo, H. Nakamura, and H. Yano, 1983, Soot and Valve Train Wear in Passenger Car Diesel Engine, SAE Paper 831757.

Nagaki, H., and K. Korematsu, 1995, "Effect of Sulfur Dioxide in Recirculated Exhaust Gas on Wear JSME International Journal, Series B, 38(3):465-474.

Nemser, S.M., and I.C. Roman, 1991, "Perfluorodioxole Membranes," U.S. Patent 5,051,114, Sept. 24.

Nemser, S.M., 1997, personal communication.

Ng, H.K., V.J. Novick, and R.R. Sekar, 1995, "Using Monatomic Nitrogen Induced by a Pulsed Arc to Remove Nitrogen Oxides from a Gas Stream," Proceedings of the ASME Fall Technical Conference, ICE 25(1): 73-80.

Pan, C.Y., and H. Habgood, 1974, "An Analysis of the Single-Stage Gaseous Permeation Process," Industrial and Engineering Chemistry Fundamentals 13(4):323-331.

Plee, S.L., T. Ahmad, and J.P. Myers, 1981, Flame Temperature Correlation for the Effects of Exhaust Gas Recirculation on Diesel Particulate and $N O_{x}$ Emissions, SAE Paper 811195.

Poola, R.B., K.C. Stork, R.R. Sekar, K. Callaghan, and S. Nemser, 1998, "Variable Air Composition with Polymer Membrane - A New Low Emissions Tool," SAE Paper 980178. 
Poola, R.B., R.R. Sekar, and D. Assanis, 1996, Application of Oxygen-Enriched Combustion for Locomotive Diesel Engines, Phase I, ANL/ESD/TM-135, Center for Transportation Research, Argonne National Laboratory, Argonne, Ill.

Psaras, D., J.C. Summers, P.K. Das, K. Ceynow, M.K. Khair, and W. DiSilverio, 1997, Achieving the 2004 Heavy-Duty Diesel Emissions Using Electronic EGR and a Cerium Based Fuel Borne Catalyst, SAE Paper 970189.

Ragland, K.W., and J.G. Whipple, 1989, Test and Evaluation of Polymeric Membranes for Oxygen-Enrichment of Air, U.S. Department of Energy, DOE/ID-12710-1.

Roman, I.C., 1996, Membranes for $N_{2}$ Generation: Recent Advances and Impact on Other Gas Separations, DuPont/L'Air Liquide, Newport, Del.

Röpke, S., G.W. Schweimer, and T.S. Strauss, 1995, "NO${ }_{\mathrm{x}}$ Formation in Diesel Engines for Various Fuels and Intake Gases," SAE Paper 950213.

Schwaar, R.H., 1991, Membranes for Gas Separations, Stanford Research Institute International, Menlo Park, Calif.

Sekar, R.R., W.W. Marr, J.E. Schaus, R.L. Cole, and T.J. Marciniak, 1990, "Diesel Engine Experiments with Oxygen Enrichment, Water Addition and Lower-Grade Fuel," Proceedings of the $25^{\text {th }}$ Intersociety Energy Conversion Engineering Conference, Vol. 4.

Stern, S.A., 1994, "Polymers for Gas Separations: The Next Decade — Review," Journal of Membrane Science (94):1-65.

Virk, K.S., U. Kokturk, and C.R. Bartles, 1993, Effects of Oxygen-Enriched Air on Diesel Engine Exhaust Emissions and Engine Performance, SAE Paper 931004.

Watson, H.C., E.E. Milkins, and G.R. Rigby, 1990, A New Look at Oxygen Enrichment — The Diesel Engine, SAE Paper 900344.

Winston Ho, W.S., and K.K. Sirkar, 1992, Membrane Handbook, Chapman \& Hall, New York, N.Y.

Yu, R.C., and S.M. Shahed, 1981, Effects of Injection Timing and Exhaust Gas Recirculation on Emissions from a DI Diesel Engine, SAE Paper 811234. 